Environmental Molecular Sciences Laboratory

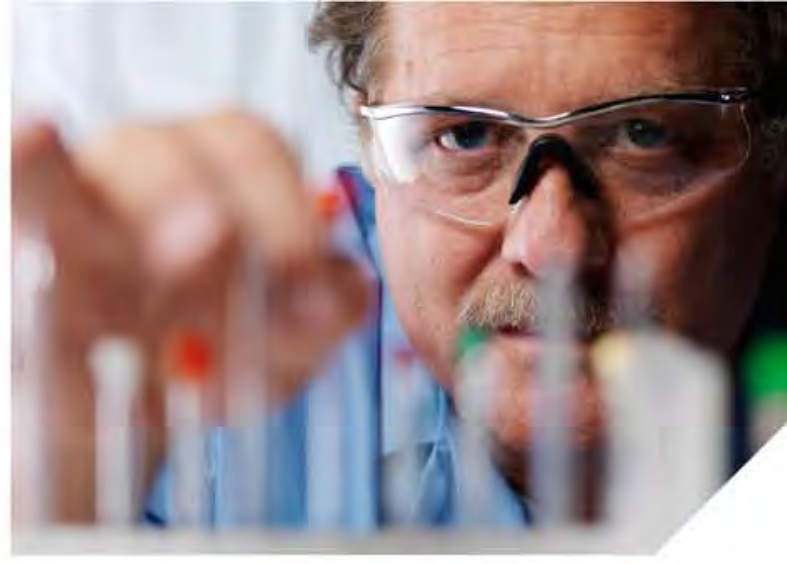

Operations Manual
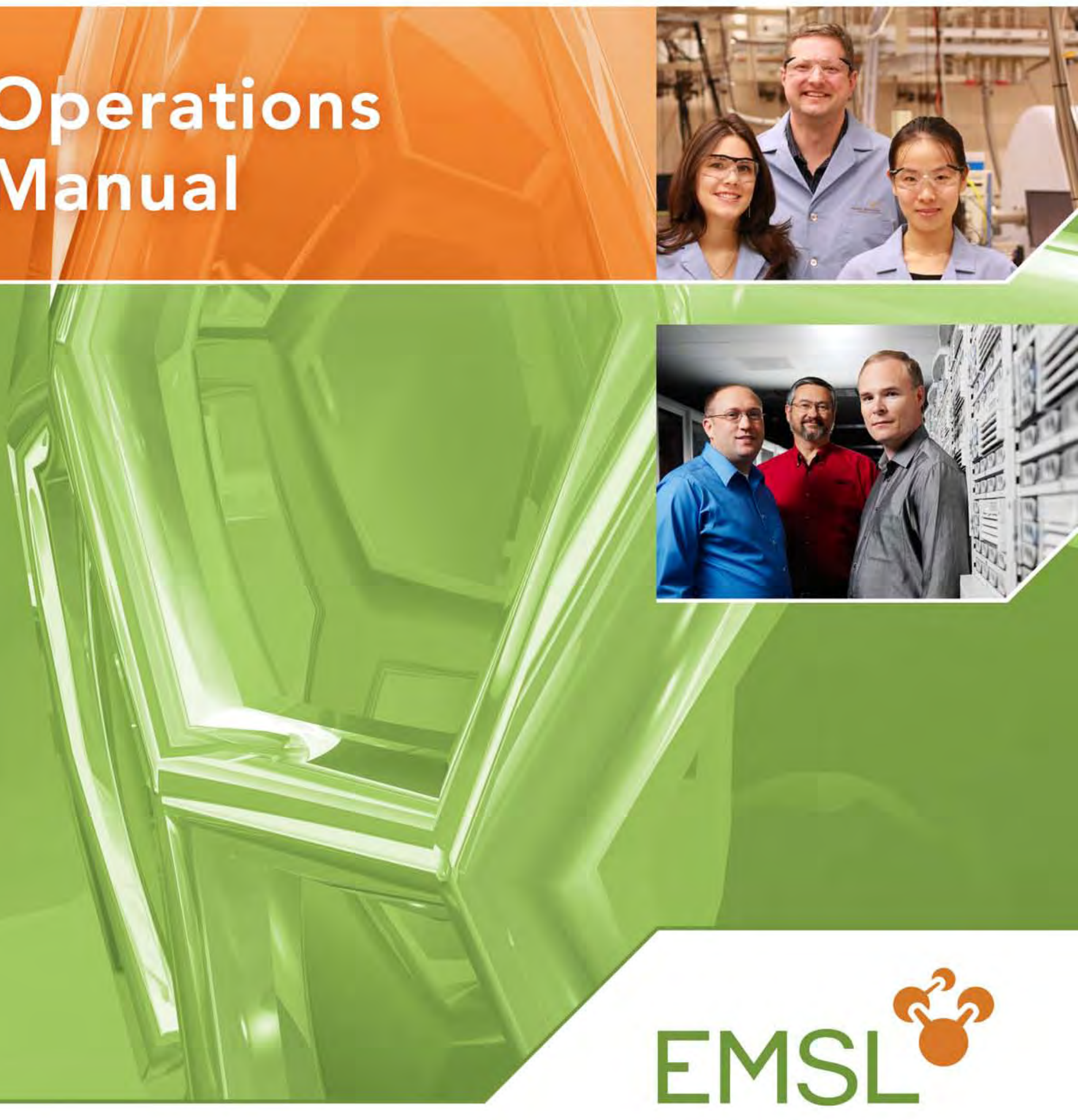


\title{
DISCLAIMER
}

This report was prepared as an account of work sponsored by an agency of the United States Government. Neither the United States Government nor any agency thereof, nor Battelle Memorial Institute, nor any of their employees, makes any warranty, express or implied, or assumes any legal liability or responsibility for the accuracy, completeness, or usefulness of any information, apparatus, product, or process disclosed, or represents that its use would not infringe privately owned rights. Reference herein to any specific commercial product, process, or service by trade name, trademark, manufacturer, or otherwise does not necessarily constitute or imply its endorsement, recommendation, or favoring by the United States Government or any agency thereof, or Battelle Memorial Institute. The views and opinions of authors expressed herein do not necessarily state or reflect those of the United States Government or any agency thereof.

\author{
PACIFIC NORTHWEST NATIONAL LABORATORY \\ operated by \\ BATTELLE \\ for the \\ UNITED STATES DEPARTMENT OF ENERGY \\ under Contract DE-AC05-76RL01830
}

Printed in the United States of America
Available to DOE and DOE contractors from the Office of Scientific and Technical Information,
P.O. Box 62, Oak Ridge, TN 37831-0062;
ph: (865) 576-8401
fax: (865) 576-5728
email: reports@adonis.osti.gov

\footnotetext{
Available to the public from the National Technical Information Service, U.S. Department of Commerce, 5285 Port Royal Rd., Springfield, VA 22161 ph: (800) 553-6847 fax: $(703) 605-6900$ email: orders@ntis.fedworld.gov online ordering: http://www.ntis.gov/ordering.htm
} 


\section{EMSL Operations Manual}

Contact: Nancy Foster-Mills

Title: EMSL Integrated Planning \& Assessment Manager

March 25, 2009

Rev 4.0

Prepared for the U.S. Department of Energy's Office of Biological and Environmental Research under Contract DE-AC05-76RL01830

Pacific Northwest National Laboratory

Richland, Washington 99352 



\section{EMSL Policy Change Request Form}

\section{EMSL Policy Change Request the EMSL Operations Manual Form}

\section{Change Request Number (to be filled in by NFM):}

\section{Date of Request:}

3. Name of Requestor:

\section{Title of Change Request}

6. Title of Section Affected (if new - provide a title):

\section{Brief description of change \& why:}

\section{Remarks:}

\section{Filename(s):}

10. PNNL Approvals:

Owner

Date

Nancy Foster-Mills

Date

EMSL Director

Date

\section{Disposition}

Version of Operations Manual affected

Version of new Operations Manual

Date new version posted

TRIM \#s

\section{Impact}

Correction

Update/Revision

Create new section

Delete section

Other

\begin{tabular}{|l|}
\hline \\
\hline Owner Date
\end{tabular}

Is DOE/PNSO notified required? $\square$ yes $\square$ no

Date of Notification:

Is DOE/PNSO approval required $\square$ yes $\square$ no Date of DOE/PNSO approval: 


\section{Change Control Record}

\begin{tabular}{|c|c|c|c|c|}
\hline Section & Date & Change & TRIM Record \# & Owner \\
\hline 1.0 Introduction & $6 / 2006$ & $\begin{array}{l}\text { - Original Document = EMSL } \\
\text { Operations Manual Rev } 3 \text { (PNNL- } \\
\text { 15828). Note - this required legal } \\
\text { review. Do not edit this section } \\
\text { without legal review. }\end{array}$ & EREC.199100 & $\begin{array}{l}\text { Nancy } \\
\text { Foster-Mills }\end{array}$ \\
\hline 2.0 Mission * & $\begin{array}{l}8 / 23 / 2005 \\
8 / 23 / 2005\end{array}$ & $\begin{array}{l}\text { - Same Policy - new TRIM \# created } \\
\text { for future updates } \\
\text { - Original Document = EMSL Action } \\
\text { Plan 2005: WBS 1.03.01; EMSL } \\
\text { Mission Statement. }\end{array}$ & $\begin{array}{l}\text { EREC.523207 } \\
\text { EREC. } 268653\end{array}$ & $\begin{array}{l}\text { Allison } \\
\text { Campbell }\end{array}$ \\
\hline 3.0 Science Themes * & $\begin{array}{l}3 / 10 / 2008 \\
12 / 28 / 2005\end{array}$ & $\begin{array}{l}\text { - Science Themes were last updated } \\
\text { before the } 2008 \text { Call for Proposals. } \\
\text { - Original Document = EMSL Action } \\
\text { Plan 2005: WBS 1.02.02; Science } \\
\text { Themes. }\end{array}$ & $\begin{array}{l}\text { EREC.523211 } \\
\text { EREC.523209 }\end{array}$ & Andy Felmy \\
\hline $\begin{array}{l}\text { 4.0 Definition of an EMSL } \\
\text { User * }\end{array}$ & $\begin{array}{l}9 / 27 / 2006 \\
10 / 3 / 2005\end{array}$ & $\begin{array}{l}\text { - Starting in FY07, the definition was } \\
\text { changed to "An individual who } \\
\text { makes use of the facility as part of an } \\
\text { active user proposal in the EMSL } \\
\text { Usage System is considered an } \\
\text { EMSL user”. } \\
\text { - Original Document = EMSL Action } \\
\text { Plan 2005: WBS 1.02.074; User } \\
\text { Definition. Thus in FY06, the } \\
\text { definition was changed to “Any } \\
\text { individual not in the EMSL line } \\
\text { organization who makes use of the } \\
\text { facility as part of an active user } \\
\text { proposal in the EUS, the EMSL user } \\
\text { proposal system is considered an } \\
\text { EMSL user.” } \\
\text { - Note - through FY05, all participants } \\
\text { on active proposals were counted as } \\
\text { users. }\end{array}$ & $\begin{array}{l}\text { EREC.523212 } \\
\text { EREC.268646 }\end{array}$ & Terry Law \\
\hline
\end{tabular}

iv

Point of Contact: EMSL Integrated Planning \& Assessment Manager, Nancy Foster-Mills Note: * Level 1 Milestone document
Previous Revision: none Current Revision: March 24, 2009 Last Reviewed: March 24, 2009 


\begin{tabular}{|c|c|c|c|c|}
\hline Section & Date & Change & TRIM Record \# & Owner \\
\hline $\begin{array}{l}\text { 5.0 EMSL Science Theme and } \\
\text { Open Call Proposal } \\
\text { Evaluation* }\end{array}$ & $\begin{array}{l}1 / 21 / 2009 \\
1 / 21 / 2009 \\
4 / 14 / 2006 \\
10 / 6 / 2005\end{array}$ & $\begin{array}{l}\text { - BER was notified that the external } \\
\text { proposal evaluation process will } \\
\text { change.. External reviewers will } \\
\text { respond to } 2 \text { criteria. The remaining } \\
3 \text { criteria will be scored by an } \\
\text { internal Science Review Panel. No } \\
\text { change was made to the criteria } \\
\text { verbiage, although they were } \\
\text { renumbered. The potential } \\
\text { considerations were slightly } \\
\text { modified. Note: only the criteria } \\
\text { (questions) are a Level } 1 \text { document. } \\
\text { - Same Review Criteria - new TRIM \# } \\
\text { created for future updates } \\
\text { - As of 4/14/2006, in general, all } \\
\text { proposals started going through peer } \\
\text { review using the } 5 \text { review criteria } \\
\text { questions. } \\
\text { - Original Document = EMSL Action } \\
\text { Plan 2005: WBS 1.02.04; User } \\
\text { Proposal Review Criteria. }\end{array}$ & EREC.523213 & Terry Law \\
\hline 6.0 Utilization Policy * & $12 / 28 / 2005$ & $\begin{array}{l}\text { - Original Document = EMSL Action } \\
\text { Plan 2005: WBS 1.02.02; EMSL } \\
\text { Utilization Plan. }\end{array}$ & EREC.268665 & Ray Teller \\
\hline $\begin{array}{l}\text { 7.0 Science Advisory } \\
\text { Committee Charter* }\end{array}$ & $12 / 30 / / 2005$ & $\begin{array}{l}\text { - Original Document = EMSL Action } \\
\text { Plan 2005: WBS 1.02.04; Charters } \\
\text { and Committees. }\end{array}$ & EREC.268625 & $\begin{array}{l}\text { Allison } \\
\text { Campbell }\end{array}$ \\
\hline $\begin{array}{l}8.0 \text { User Advisory Committee } \\
\text { Charter * }\end{array}$ & $10 / 6 / 2005$ & $\begin{array}{l}\text { - Original Document = EMSL Action } \\
\text { Plan 2005: WBS 1.02.04; Charters } \\
\text { and Committees. }\end{array}$ & EREC.268626 & $\begin{array}{l}\text { Allison } \\
\text { Campbell }\end{array}$ \\
\hline $\begin{array}{l}\text { 9.0 Charging Guidance for } \\
\text { EMSL User Facility Staff }\end{array}$ & $\begin{array}{l}2 / 28 / 2007 \\
10 / 6 / 2005\end{array}$ & $\begin{array}{l}\text { - Significantly updated } \\
\text { - Original Document = Appendix C of } \\
\text { the } 2006 \text { Operations Manual }\end{array}$ & $\begin{array}{l}\text { EREC.522875 } \\
\text { EREC.522875 r1 }\end{array}$ & Peter Smith \\
\hline 10.0 Space Policy & $\begin{array}{l}2 / 3 / 2009 \\
\text { May } 2006\end{array}$ & $\begin{array}{l}\text { - Last updated for the Operations } \\
\text { Manual (Feb 2009). No significant } \\
\text { changes, mainly updating } \\
\text { terminology. } \\
\text { - Original Document = Staff Resource } \\
\text { Guide May 2006. }\end{array}$ & $\begin{array}{l}\text { EREC. } 516400 \\
\text { EREC. } 516400 \mathrm{r} 1\end{array}$ & Joy Rosscup \\
\hline $\begin{array}{l}11.0 \text { Guidance and Examples } \\
\text { regarding designation of } \\
\text { User(s) in ERS bookings } \\
\text { (formally known as Who is a } \\
\text { User Memo) }\end{array}$ & $\begin{array}{l}3 / 18 / 2009 \\
5 / 27 / 2007\end{array}$ & $\begin{array}{l}\text { - Updated User Definition and Title } \\
\text { (per Sect.4). No other changes. } \\
\text { - Original Document }\end{array}$ & $\begin{array}{l}\text { EREC.517611 } \\
\text { EREC.517611 r1 }\end{array}$ & Ray Teller \\
\hline
\end{tabular}




\begin{tabular}{|c|c|c|c|c|}
\hline 12.0 Usage Types & $\begin{array}{l}2 / 24 / 2009 \\
10 / 31 / 2006 \\
\text { June } 2006\end{array}$ & $\begin{array}{l}\text { - Revision to show EMSL } 5 \% \text { as new } \\
\text { usage type. Note: Participants } \\
\text { selecting EMSL } 5 \% \text { will not be } \\
\text { counted as users as of FY09. } \\
\text { - Revision to clarify and give } \\
\text { examples. } \\
\text { - Original document in June } 2006 \\
\text { Operations Manual }\end{array}$ & $\begin{array}{l}\text { EREC.522858 } \\
\text { EREC.522858 r2 } \\
\text { EREC.522858 r1 }\end{array}$ & Terry Law \\
\hline $\begin{array}{l}\text { 13.0 Non-Proprietary Use } \\
\text { Agreement and Appendices }\end{array}$ & $\begin{array}{l}10 / 1 / 1998 \\
10 / 1 / 19998 \\
7 / 12 / 2006 \\
10 / 1 / 1998 \\
10 / 1 / 1998\end{array}$ & $\begin{array}{l}\text { - NPUA } \\
\text { - Appendix A } \\
\text { - Appendix B - updated to include } \\
\text { “"PNNL/EMSL research staff are } \\
\text { often listed as co-authors on } \\
\text { publications resulting from User } \\
\text { research performed in EMSL due to } \\
\text { their significant scientific } \\
\text { contribution. If PNNL/EMSL staff } \\
\text { are listed as co-authors, you are } \\
\text { required to notify the staff member } \\
\text { prior to submission so that the } \\
\text { publication can be reviewed and } \\
\text { processed through PNNL's clearance } \\
\text { system” in Section } 6 . \\
\text { - Appendix C }\end{array}$ & $\begin{array}{l}\text { EREC.523033 } \\
\text { EREC.523175 } \\
\text { EREC.523036 }\end{array}$ & Terry Law \\
\hline $\begin{array}{l}\text { 14.0 EMSL Staff } 5 \% \\
\text { Proposals Implementation and } \\
\text { Utilization }\end{array}$ & $2 / 24 / 2009$ & - Original document. & EREC.518296 & Terry Law \\
\hline 15.0 Appeal Process & $\begin{array}{l}3 / 17 / 2009 \\
5 / 27 / 2008\end{array}$ & $\begin{array}{l}\text { - Revised text - increased the number } \\
\text { of paragraphs (from 1-2 to 2-3), and } \\
\text { decreased the response time (from } 8 \\
\text { to } 4 \text { weeks). } \\
\text { - Original - as posted on EMSL } \\
\text { website }\end{array}$ & $\begin{array}{l}\text { EREC.522905 } \\
\text { EREC.522905 - } \\
\text { see general notes }\end{array}$ & Terry Law \\
\hline $\begin{array}{l}\text { 16.0 EMSL Partner Proposals } \\
\text { for Capability Development } \\
\text { Process for Submission and } \\
\text { Review }\end{array}$ & 3/4/2009 & - Original & EREC.519323 & Dave Koppenaal \\
\hline
\end{tabular}

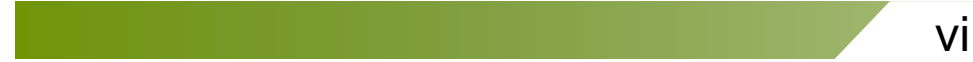

Point of Contact: EMSL Integrated Planning \& Assessment Manager, Nancy Foster-Mills Note: * Level 1 Milestone document
Previous Revision: none

Current Revision: March 24, 2009 Last Reviewed: March 24, 2009 


\section{Acronyms and Abbreviations}

BER DOE Office of Science, Office of Biological and Environmental Research

CSM Cognizant Space Manager

DOE U.S. Department of Energy

EMSL Environmental Molecular Sciences Laboratory

ERS EMSL Resource System

ES\&H Environment, Safety and Health

EUS EMSL Usage System

IDL Instrument Development Laboratory

IOPS Integrated Operations System

NMR nuclear magnetic resonance

PNNL Pacific Northwest National Laboratory

SAC Science Advisory Committee

SBMS PNNL Standards-Based Management System

UAC User Advisory Committee 



\section{Contents}

EMSL Policy Change Request Form .......................................................................................... iii

Change Control Record...................................................................................................... iv

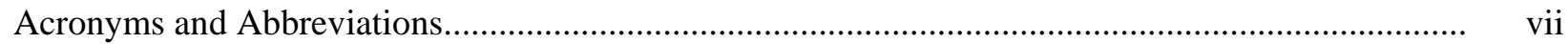

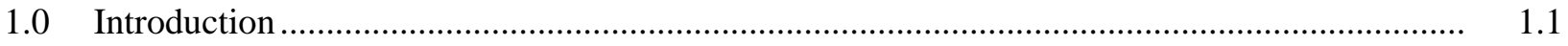

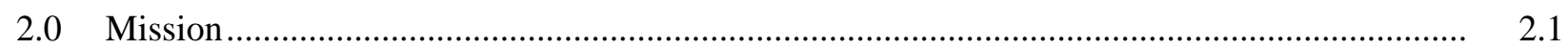

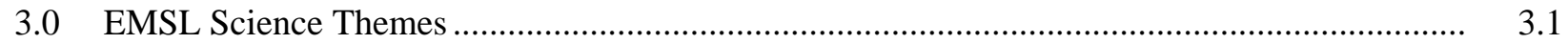

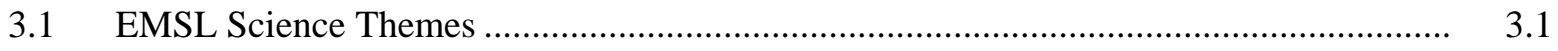

3.2 Atmospheric Aerosol Chemistry .............................................................................

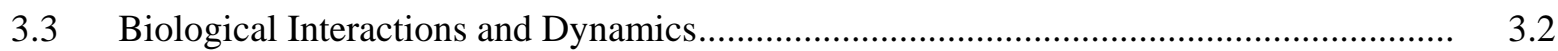

3.4 Geochemistry/Biogeochemistry and Subsurface Science ............................................ 3.3

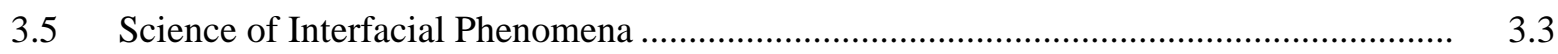

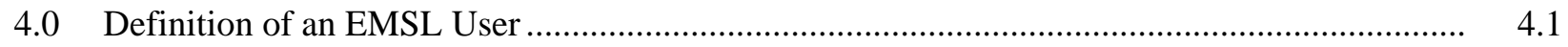

5.0 EMSL Science Theme and Open Call Proposal Evaluation ................................................. 5.1

6.0 EMSL Utilization Policy ...................................................................................... 6.1

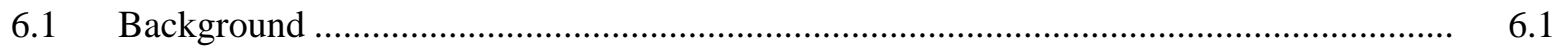

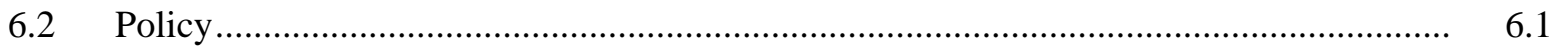

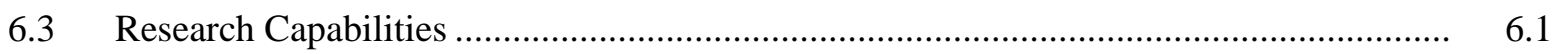

7.0 Science Advisory Committee Charter .............................................................................. 7.1

7.1 Committee Function and Objectives …..........................................................................

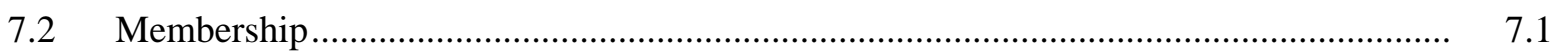

7.2.1 Size of Committee and Selection Process......................................................... $\quad 7.1$

7.2.2 Qualifications........................................................................................ 7.1

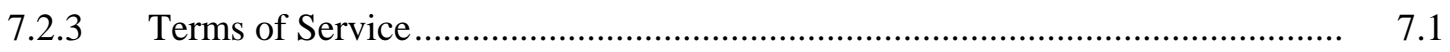

7.2.4 EMSL Staff Coordinator............................................................................. 7.2

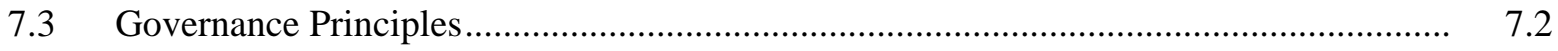

7.3.1 Role of Management............................................................................. 7.2

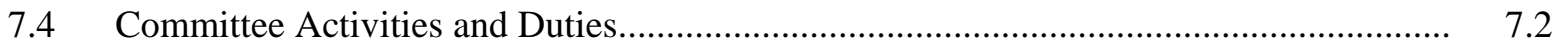

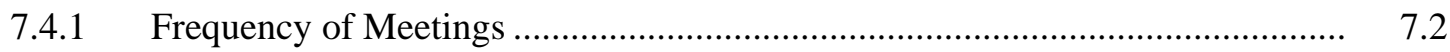

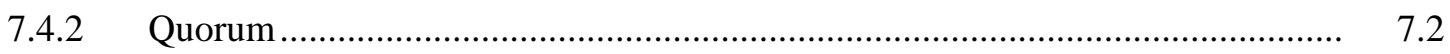

7.4.3 Setting Committee Agenda ........................................................................ 7.2

7.4.4 Formation of Subcommittees....................................................................... 7.3

7.4.5 Self-Assessment.......................................................................................

7.4.6 Reimbursement or Honoraria for Committee Members ..................................... 7.3

7.4.7 Access to EMSL Management …………............................................................ 7.3

7.4.8 Committee Member Orientation ................................................................ 7.3

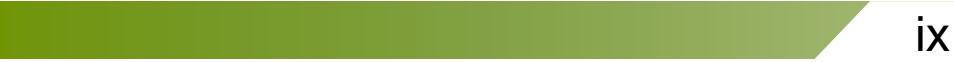

Point of Contact: EMSL Integrated Planning \& Assessment Manager, Nancy Foster-Mills
Previous Revision: Operations Manual Rev. 3, June, 2006

Current Revision: March 13, 2009 Last Reviewed: March 13, 2009 
8.0 User Advisory Committee Charter

8.1 Committee Function and Objectives …..................................................................... 8.1

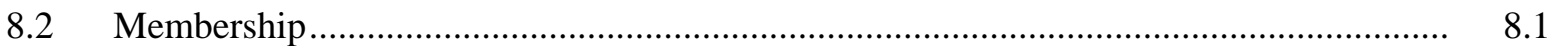

8.2.1 Size of Committee and Selection Process........................................................ 8.1

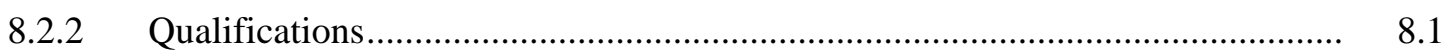

8.2.3 Terms of Service.............................................................................. 8.2

8.2.4 EMSL Staff Coordinator............................................................................ 8.2

8.3 Governance Principles..................................................................................... 8.2

8.3.1 Role of Management...................................................................................... 8.2

8.3.2 Role of the User Advisory Committee ….......................................................... 8.2

8.4 Committee Activities and Duties................................................................................ 8.3

8.4.1 Frequency of Meetings …............................................................................. 8.3

8.4 .2 Quorum ........................................................................................... 8.3

8.4.3 Setting Committee Agenda ...................................................................... 8.3

8.4.4 Formation of Subcommittees.................................................................... 8.3

8.4.5 Self-Assessment ............................................................................... 8.4

8.4.6 Reimbursement or Honoraria for Committee Members ..................................... 8.4

8.4.7 Access to EMSL Management .......................................................................... 8.4

8.4.8 Committee Member Orientation ............................................................... 8.4

9.0 Charging Guidance for EMSL User Facility Staff .......................................................... 9.1

9.1 Support Activities Charged to the EMSL Project ............................................................ 9.1

9.2 Support Activities Charged to other projects ................................................................. 9.2

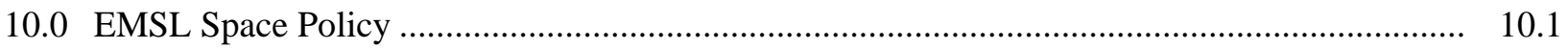

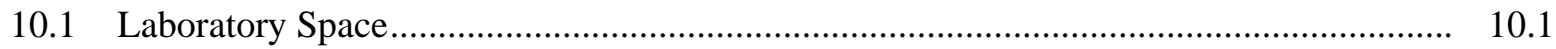

10.1.1 Requesting EMSL Laboratory Space ......................................................... 10.2

10.1 .2 Office Space....................................................................................... 10.2

11.0 Guidance and Examples Regarding Designation of User(s) in ERS bookings ........................ 11.1

12.0 Usage Type Definitions................................................................................................. 12.1

13.0 Non-Proprietary Use Agreement (NPUA) \& Appendices .................................................... 13.1

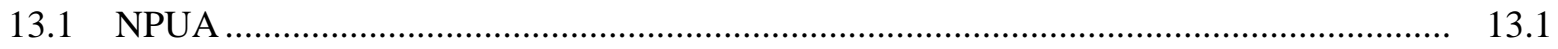

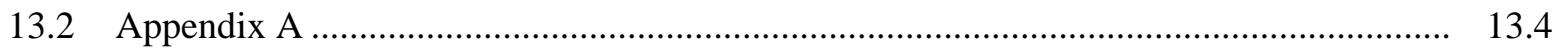

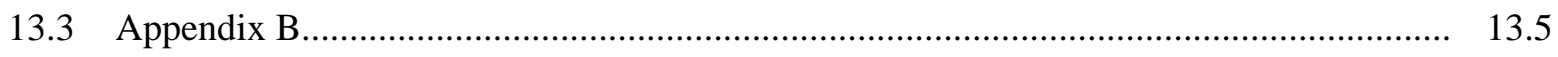

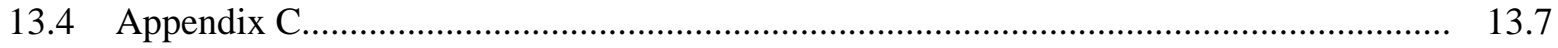


14.0 EMSL Staff 5\% Proposals Implementation and Utilization

14.1

15.0 Appeals.

15.1

16.0 EMSL Partner Proposals for Capability Development

16.1

16.1 Definition. 16.1

16.2 Review Process - Letters of Intent 16.1

16.3 Review Process - Full Proposals. 16.1

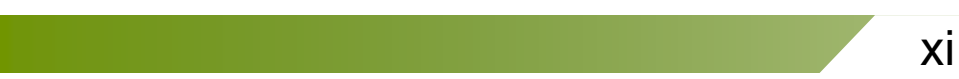

Point of Contact: EMSL Integrated Planning \& Assessment Manager, Nancy Foster-Mills
Previous Revision: Operations Manual Rev. 3, June, 2006

Current Revision: March 13, 2009 Last Reviewed: March 13, 2009 



\subsection{Introduction}

EMSL - Environmental Molecular Sciences Laboratory, a national scientific user facility, provides integrated experimental and computational resources for discovery and technological innovation in the environmental molecular sciences to support the needs of the U.S. Department of Energy (DOE) and the nation. EMSL's vision is to be the soughtafter leader in developing solutions to complex scientific challenges of national importance, and will accomplish and deliver accelerated, leadership-class science through multidisciplinary collaborations with an engaged, proactive user community; expert scientists and staff; and state-of-the-art signature capabilities.

This manual is a general resource tool to assist EMSL users and Laboratory staff within EMSL locate official policy, practice and subject matter experts. It is not intended to replace or amend any formal Battelle policy or practice. Users of this manual should rely only on Battelle’s Standard Based Management System (SBMS) for official policy. No contractual commitment or right of any kind is created by this manual. Battelle management reserves the right to alter, change, or delete any information contained within this manual without prior notice.

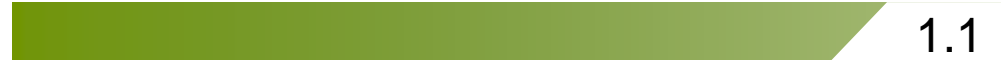

Point of Contact: EMSL Integrated Planning \& Assessment Manager, Nancy Foster-Mills Note: Needs Legal Review prior to any changes
Previous Revision: Operations Manual Rev. 3, June, 2006 Current Revision: Operations Manual Rev. 3, June, 2006 Last Reviewed: March 2, 2009 



\subsection{Mission}

EMSL, a U.S. Department of Energy national scientific user facility located at Pacific Northwest National Laboratory provides integrated experimental and computational resources for discovery and technological innovation in the environmental molecular sciences to support the needs of DOE and the nation. 



\subsection{EMSL Science Themes}

\subsection{EMSL Science Themes}

The vision that directed the development of the Environmental Molecular Sciences Laboratory (EMSL) has led to significant scientific progress. EMSL plans to maintain its scientific impact during a second decade of operation by focusing attention and capability development in specific areas identified as high-priority science themes. These science themes help define and direct development of key capabilities and collections of user projects that can have significant impacts on important areas of environmental molecular science that are critical to DOE and the nation. The science themes provide the basis for decision making by EMSL management on future investments in expertise and capital equipment.

Because the Environmental Molecular Sciences Laboratory is a National Scientific User Facility for the U.S. Department of Energy, science themes are selected to meet key criteria including relevance to DOE and the nation, impactful environmental molecular science, and the ability to grow a vibrant national user program.

With these factors in mind, EMSL, in collaboration with the scientific community, DOE's Office of Biological and Environmental Research (BER) leadership, and our Science Advisory Committee has selected four science themes: Atmospheric Aerosol Chemistry, Biological Interactions and Dynamics, Science of Interfacial Phenomena, and Geochemistry/Biogeochemistry and Subsurface Science. Within each of these science themes, more directed topical areas are being developed. Each of these four themes is described briefly below.

\subsection{Atmospheric Aerosol Chemistry}

Atmospheric aerosols play an important role in global climate change. Variations of aerosols are recognized as a significant forcing factor that alters the planetary radiation balance onto and away from the Earth, thus contributing to global temperature change. The effects of climate forcing caused by aerosols are not well understood, especially in the case of anthropogenic aerosols. Indeed, the effect of aerosols has been one of the greatest sources of uncertainty in efforts to interpret climate change that occurred in the past century and to project future climate change.

This science theme is designed to advance the state of knowledge of aerosol physics and chemistry from the molecular level to regional and global scales and their impacts on climate change. State-of-the-art instrumentation at EMSL will be used to characterize the size, composition, density, morphology, chemical reactivity, and cloud interactions of aerosol particles. The research will employ a collaborative, comprehensive, and interdisciplinary approach that will combine both the unique analytical capabilities of EMSL and the research expertise of EMSL scientific staff and the user community.

This science theme is formulated around the following specific, key scientific topical areas that the aerosol chemistry and atmospheric science communities face today and will continue to face in the future:

- Developing a novel analytical platform for comprehensive chemical and physical characterization of organic aerosols

- Evaluating dynamics of cloud-aerosol interactions and their climatic impacts

- Gaining critical knowledge of life cycle and long-term aging of aerosols in the atmospheric environment.

Point of Contact: EMSL Lead Scientist, Andrew Felmy

Note: Level 1 Document; Requires DOE approval
3.1

Previous Revision: December 28, 2005 Current Revision: March 10, 2008 Last Reviewed: March 4, 2009 
Understanding the role of aerosols in climate change is an important scientific challenge that is critical to more accurately predict the environmental impact of future energy technology options. This science theme addresses the chemical and physical properties of organic aerosols that are of key relevance to cloud formation and climate change. Aerosols are constantly evolving, and the changes they undergo profoundly alter their impact and even how long they live or how far they travel. Providing the scientific foundation to better predict how and when these properties change is necessary so policy makers can make environmentally sound decisions about process that generate aerosols.

\subsection{Biological Interactions and Dynamics}

Understanding and optimizing the response or performance of biological systems to the interaction with its environment can have a significant impact on achieving viable solutions to several problems of national concern. For example, anaerobic microbial metabolism is of direct relevance to national missions in environmental cleanup and site stewardship, clean and secure energy, and basic science. Thus, molecular-level measurements and the corresponding insight into biochemical processes could lead to new predictive computational models that provide an improved basis for using microbes effectively and safely to mitigate the impacts of energy production activities on the environment and human health.

Recent advances in whole-genome sequencing for a variety of organisms and improvements in high-throughput instrumentation have contributed to a rapid transition of the biological research paradigm towards understanding biology at a systems level. As a result, biology is evolving from a descriptive to a quantitative, ultimately predictive science where the ability to collect and productively use large amounts of biological data is crucial. Understanding how the ensemble of proteins in cells gives rise to biological outcomes is fundamental to systems biology. These advances will require new technologies and approaches to measure and track the temporal and spatial disposition of proteins in cells and how protein complexes give rise to specific activities.

To help facilitate the transition of biology to a more quantitative science, the EMSL will develop capabilities, and encourage user proposals, with a focus on key topical areas:

- Understanding the protein and metabolite composition of cells as well as the activities and structures of individual proteins or protein complexes.

- The dynamics of protein composition or localization, and their assembly into multiprotein complexes.

- Investigating properties of biological membranes and the interaction of cells with their environment.

The expanded understanding of the structure, function, and dynamics of multi-protein complexes will provide information needed for optimizing the response of biological systems (e.g., microbes) in particular environments such as those associated with fuel production or contaminant metabolism. Metabolite profiling will improve our understanding of how cells respond to changes in their environment or energy state. These efforts will require extending current capabilities in high-throughput mass spectrometry and NMR. Enhanced capabilities to examine microbial membranes and interfacial interactions will require the development of new techniques, such as cryo-TEM, and multimodal and multispectral microscopy. These techniques generate large amounts of data that will be handled by an integrated data management system. 


\subsection{Geochemistry/Biogeochemistry and Subsurface Science}

One of the most challenging and pressing issues confronting DOE and the Nation is the safe and cost-effective management of environmental pollutants and the remediation of hazardous waste sites. DOE is responsible for managing some 40 million cubic meters of contaminated soils and 1.7 trillion gallons of contaminated groundwater. Across the United States, thousands of Superfund sites exist with various levels and types of contamination (e.g., organic materials, heavy metals, inorganic materials, radionuclides).

Molecular level processes, such as aqueous complexation, adsorption to different mineral phases, or microbial reduction of redox active metals, often control the transport and fate of contaminants in the environment. These processes occur in complicated subsurface environments that are chemically and physically heterogeneous. Understanding the structure, chemistry, and nano-scale geometric properties of the mineral/water and microbe/mineral interfaces are therefore key aspects of developing a mechanistic understanding of contaminant transport. As a result molecular level studies of interfacial geochemistry and biogeochemical reactions have been an active area of research for more than a decade. Unraveling these phenomena at the molecular level and determining their impact on contaminant migration and transformation in the environment is a key objective of this science theme area.

This science theme will focus EMSL's scientific resources on the following key topical areas:

- Interfacial molecular geochemistry and biogeochemistry

- Understanding the chemistry of radionuclides in the subsurface

- Understanding the fact and transport of chemical and microbial species in the subsurface.

Research in the area of biogeochemistry and subsurface science is well established in EMSL. We propose to build on our strength in that area by focusing on key scientific questions/challenges in the area of molecular geochemistry and biogeochemistry, linking Subsurface Flow and Transport Experimental Laboratory capabilities to molecular-science capabilities, and gaining better access to use of radioactive materials.

\subsection{Science of Interfacial Phenomena}

Interfaces control many chemical and physical properties of natural and engineered materials critical to environmental and energy related research and technology. Tailored or designed surfaces and interfaces are important both as model systems for detailed study of processes that occur on natural heterogeneous materials in the environment and to design materials with new properties for technological use, such as energy production or catalysis. It is likely that the behaviors of complex heterogeneous materials in the environment can never be fully understood without model systems that allow specific aspects of that complexity to be examined in detail.

Likewise, material systems with interfaces optimized to have specific properties are essential for the advanced technologies needed for a secure environment and a stable energy future for the nation.

Examples of technologies that rely on improved understanding and control of molecular-level structural, dynamic, and transport properties of interfaces include: hydrogen production and storage, chemical sensors and radiation detectors, solid-oxide fuel cell research and development, materials for next-generation nuclear reactors, thin-film solar cells, new generations of selective catalysts, and the development of solid-state lighting.

Point of Contact: EMSL Lead Scientist, Andrew Felmy

Note: Level 1 Document; Requires DOE approval

\section{3}

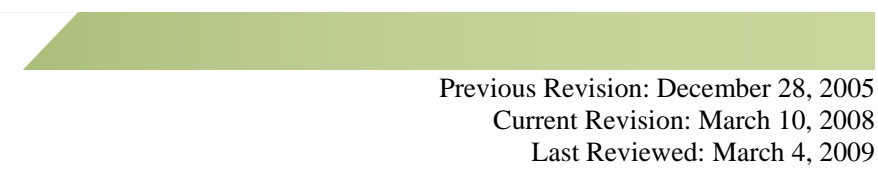


Because of their environmental importance EMSL has become a premier laboratory for the study of oxide materials and mineral surfaces. These materials have an increasing importance in many new technology areas and will remain our main focus. As such, it is crucial to understand the scientific issues associated with designed surfaces and interfaces that can be effectively used in a particular physical and chemical process. Compared to what is known at the atomic and molecular levels for metal and semiconductor materials, much less is known about metal oxides. The complexity of the structures involved often makes them difficult to study, both theoretically and experimentally. The scientific expertise developed over the past years and the research capabilities available at EMSL are ideally suited to helping advance our understanding of these scientific issues.

Interfacial research activities associated with environmental geochemistry, biology, and atmospheric chemistry are not covered here because these are being captured under the science themes of Biogeochemistry and Subsurface Science, Biological Interactions and Dynamics, and Atmospheric Aerosol Chemistry. In particular, this science theme will focus on the following topical areas:

- Catalytic structure-function relationships to allow precise control of catalytic activity and selectivity

- Gaining critical knowledge of photocatalysis and photochemistry

- Design material systems with specialized charge and mass transport properties.

This science theme focuses on developing an understanding of catalytic structure-function relationships at the atomic level that will allow precise control of catalytic activity and selectivity. In addition, the science will address in a definitive and comprehensive way, for the first time, the effect of nanoscaling on the surface chemistry of well-defined metal oxides. Highly controlled experiments in the growth, characterization, and reactivity of oxide nanodots and continuous films of nanometer thickness will elucidate the effects of quantum confined and strain-driven electronic structures on the thermaland photo-chemistries of select materials. The research capabilities and expertise in EMSL will also enable the design of material systems with specialized atomic, electronic, and ionic transport properties. EMSL is an ideal place for this research to be performed because it is a premier oxide laboratory and has provided the foundation for several current research areas including surface chemistry and catalysis. As part of this research, several one-of-a-kind capabilities are planned for development in the near future. These capabilities will make EMSL a unique facility that will attract many world-class scientists as users. 


\subsection{Definition of an EMSL User}

To accomplish reliable and consistent reporting to DOE on the research community using EMSL facilities, an agreedupon EMSL user definition is necessary.

User Definition: An individual who makes use of the facility as part of an active user proposal in the EMSL Usage System is considered an EMSL user. Each user will be categorized as a/an:

- Onsite User - individuals who are physically present at EMSL, at least once during the reporting period, to conduct their research.

- Remote User, Operating Instrumentation - individuals who remotely access EMSL by logging onto EMSL's network to operate a piece of research instrumentation.

- Remote User, Not Actively Operating Instrumentation - individuals who remotely access EMSL but do not actively operate instrumentation (such as those who send/receive samples to/from EMSL).

User Counts: Users are counted once per fiscal year.

Reporting: Reports will be generated quarterly and will contain year-to-date counts. 



\subsection{EMSL Science Theme and Open Call Proposal Evaluation}

Background: Proposals submitted to EMSL will be peer reviewed. Reviewers will be asked to fill out a proposal review form providing comments and answering a subset of the following questions to ensure that the proposed research is of high quality and an appropriate use of EMSL's resources.

Criterion 1. What is the scientific merit and quality of the proposed research?

- Potential considerations: How important is the proposed activity to advancing knowledge and understanding within its own field or across different fields? To what extent does the proposed activity suggest and explore creative and original concepts? How well conceived and organized is the proposed activity?

Criterion 2. Does the proposed research have the potential to contribute significantly to highly cited publication(s)?

- Potential considerations: If successful, would the proposed research be publishable in high impact journals (i.e., top 10 journals)? Would the results help fill missing gaps required for a publication? Does the proposal team possess the breadth of skill/knowledge to successfully perform or contribute to the proposed research?

Criterion 3. How relevant is the proposed research to EMSL's mission?: "EMSL, a national scientific user facility at Pacific Northwest National Laboratory, provides integrated experimental and computational resources for discovery and technological innovation in the environmental molecular sciences to support the needs of DOE and the nation.”

- Potential considerations: What is the relationship of the proposed research to EMSL's mission? To what level are both experimental and computational resources synergistically utilized to address the proposed research?

Criterion 4. How well does the proposed research significantly impact an EMSL science theme?

- Potential considerations: Will the proposed research advance scientific and/or technological understanding of issues pertaining to a particular EMSL science theme? To what extent does the proposed research suggest and explore creative and original concepts related to a particular EMSL science theme?

Criterion 5. How appropriate and reasonable are the requested EMSL resources for the proposed research?

- Potential considerations: Are EMSL capabilities and resources essential to performing this research? Are the proposed methods/approaches optimal for achieving the scientific objectives of the proposal? Are the requested resources reasonable and appropriate for the proposed research? Does the complexity and/or scope of effort justify the duration of the proposed project-including any modifications to EMSL equipment to carry out research? Is the specified work plan practical and achievable for the proposed research project? Is the amount of time requested for each piece of equipment clearly justified and appropriate?

Excellent: Outstanding proposal in all respects, deserves highest priority for support.

Very Good: High quality proposal in nearly all respects; should be supported if at all possible.

Good: A quality proposal, worthy of support.

Fair: Proposal lacking in one or more critical aspects; key issues need to be addressed.

Poor: Proposal has serious deficiencies.

The process described herein is the result of benchmarking the EMSL proposal process with that of other DOE national user facilities. This new process will be utilized for evaluating theme and open call proposals beginning in FY09. This process will not apply for Rapid Access, Proprietary, Partner, Resource Owned, or EMSL Staff 5\% proposals.

Point of Contact: User Support Office Manager, Terry Law

Note: Review Criteria (Questions) are a Level 1 Document; Requires DOE approval
Previous Revision: October 6, 2005

Current Revision: March 4, 2009

Last Reviewed: March 23, 2009 
1. External peer review for scientific content and impact

2. Science Panel review for alignment with EMSL strategies

3. Time allocations by an Instrument Time Allocation committee (ITAC)

External peer review: After triage in the USO, proposals will be reviewed by external peer reviewers, as identified by capability stewards (CS), for scientific merit and quality of the proposed research (ability to produce impactful science). Specific questions asked of reviewers are:

- Criterion 1. What is the scientific merit and quality of the proposed research?

- Criterion 2. Does the proposed research have the potential to contribute significantly to highly cited publication(s)?

Two reviews will be obtained for each proposal. If the scores returned are separated by two or more points, then a third review will be obtained. Proposals may not be approved based on a single review without concurrence by the Appeals Committee.

EMSL science panel review: Each proposal will be assigned a CS and a science lead. Panels shall be comprised of one or more science leads, the appropriate CSs and, at the discretion of the science lead, external members taken from the EMSL SAC or any other relevant technical reviewers. A graded approach can be employed for this step in the process. For example, theme proposals that require significant EMSL resources should be rigorously reviewed by a panel to insure the resource allocation is justified. Alternatively, proposals that do not require significant resources (for example, a small number of open call proposals) can be reviewed by the science lead in consultation with the CS. It is the responsibility of each panel to evaluate the proposals by considering (a) the external peer review scores, (b) applicability to EMSL science directions, and (c) alignment with EMSL science themes and/or research campaigns. To help evaluate the proposals applicability and alignment with EMSL science directions, panels will be asked to score the proposals on the following three criteria:

- Criterion 1. Relevance of the proposed research to EMSL's mission.

- Criterion 2. Impact of the proposed research on one or more EMSL Science Themes.

- Criterion 3. Appropriateness and reasonableness of the request for EMSL resources for the proposed research.

Using these scores in addition to the external peer review score, panels will forward recommended actions for each proposal to the ITAC.

Instrument Time Allocation Committee (ITAC): The ITAC has the responsibility to act on panel recommendations and allocate time for all EMSL instruments in response to user calls and throughout the year. The ITAC will consider requests for extension against incoming proposals.

The committee shall be comprised of the EMSL ADs (co-chairs), the CSs and a USO representative. Panel recommendations as communicated by the CSs form the basis for ITAC deliberations. The committee will strive to reach a consensus for all instrument time. A graded approach should be utilized in this step. High resource allocations should be the subject of full committee meetings and deliberations. Routine or low resource needs can be addressed by a committee co-chair in consultation with other committee members as needed.

Based on the final decisions by the ITAC and concurrence by the EMSL director, the USO shall issue approval letters to the PIs, including the specific instrument time allocation and Science Points of Contact. Denial letters will direct PIs to the User Portal to view peer reviewer comments.

Point of Contact: User Support Office Manager, Terry Law

Note: Review Criteria (Questions) are a Level 1 Document; Requires DOE approval 


\subsection{EMSL Utilization Policy}

\subsection{Background}

EMSL, a national scientific user facility, provides integrated experimental and computational resources for discovery and technological innovation in the environmental molecular sciences to support the needs of DOE and the nation. The User Program is housed primarily within the EMSL building, a 200,000 square-foot research facility that is funded by BER, although it also includes capabilities housed in other PNNL facilities (e.g., radiological NMR capabilities).

\subsection{Policy}

This plan outlines the policies and procedures for using EMSL and is focused on maximizing the benefit to the User Program. All research performed in EMSL or utilizing EMSL capabilities must provide benefit to the User Program and will be managed by an active user proposal in the EUS. Access to all major systems, as defined by EMSL management and BER, are tracked by the ERS and reported to the EMSL and PNNL directors and BER. Analysis of this data is used to determine the level of continued support and schedule for retirement of capabilities. Lab space for all activities in the EMSL facility is subject to the EMSL Space Policy as detailed in the Staff Resource Guide.

\subsection{Research Capabilities}

EMSL's experimental and computational instrumentation (resources) are funded from a variety of sources. The majority of the capabilities are $100 \%$ owned by the EMSL User Program. Some capabilities were purchased using non-User Program funding and this equipment is owned by other programs. Additionally, some capabilities are co-funded by the User Program and other programs. The EMSL User Program will participate in co-funding research capabilities and allow other programs to place capabilities within the walls of EMSL only when benefit to the program is clearly demonstrated. The User Program provides significant support to all research performed in the facility, including:

- EMSL infrastructure support

- Computer and network support

- Machine shop access

- Waste management costs

- ES\&H support

- Laboratory space and the associated costs

- Collaborations with scientific leads through the EMSL User Program.

To ensure benefit to the user community, access to instrumentation is defined below by funding source. Available time is defined as all time that the equipment is not undergoing maintenance, upgrades, repair, or capability development. Capability development time by EMSL staff is justified and approved through capability development proposals, which are part of the annual request for funding by each of the EMSL scientific facilities. 
- 100\% User Program-funded research capabilities:

- At least 95\% of the available time is allotted for users through the EUS; priority will be assigned based on the impact of the proposal and the applicability of the science to EMSL's mission, vision, and science themes.

- Up to 5\% of the available time is made available for EMSL staff members to perform their independent research. Requests will be submitted through EUS for tracking purposes. Access is subject to review and approval by the Associate Director for Scientific Resources. Access will be prioritized based on research that advances EMSL's mission.

- $100 \%$ Other Program-funded research capabilities:

- $\quad 20 \%$ of the available time will be made available for users through the user proposal process unless a separate agreement is developed with the EMSL Director.

- The balance of the time is dedicated to the program that procured the systems. The utilization agreement is documented by instrument or system of instruments in the ERS and revisited whenever a major upgrade of the system occurs, and no less than every three years.

- Co-funded research capabilities:

- Users submitting a user proposal are given priority on the portion of the instrument purchased by the User Program. For example, if the User Program paid half the cost of the system, then half of the access is made available to users. However, 5\% of this portion will be allocated to EMSL staff members to perform their independent research.

- $\quad$ Time made available for EMSL staff members to perform their independent research will be submitted through EUS for tracking purposes. Access is subject to review and approval by the Associate Director for Scientific Resources. In all cases, access will be prioritized based on research that advances EMSL's mission.

- $\quad$ The remaining time will be allocated to the program that co-funded the research capabilities.

EMSL Associate Director, Scientific Resources, Ray Teller Note: Level 1 Document; Requires DOE approval 


\subsection{Science Advisory Committee Charter}

\subsection{Committee Function and Objectives}

The Science Advisory Committee (Committee or SAC) of the William R. Wiley Environmental Molecular Sciences Laboratory (EMSL) is chartered by the EMSL Director and reports to the Pacific Northwest National Laboratory Director. The SAC is chartered to render advice, guidance, and counsel on the effective management and strategic objectives of EMSL. The SAC serves as the EMSL Director's key external advisor and advocate of EMSL strategy, operations, and scientific relevance and quality. The SAC does not perform management functions nor does it direct the EMSL Director or his/her management team how to operate and manage EMSL.

\subsection{Membership}

\subsubsection{Size of Committee and Selection Process}

The members are appointed by the EMSL Director. The membership will consist of at least 10 external (non-PNNL/non-Battelle) advisors with knowledge of and influence in the major research and development areas that EMSL serves. No more than 2 members of the full committee may be Battelle/ PNNL employees. Members of the Committee may propose nominees for consideration at any time by submitting the names and supporting information to the EMSL Director. The Chair of EMSL’s User Advisory Committee is an ex-officio member of the Committee.

\subsubsection{Qualifications}

Members of the Committee and its subcommittees should possess the highest personal and professional ethics, integrity, and values, and be committed to representing the long-term interests of EMSL and the EMSL mission. They must also have an inquisitive and objective perspective, practical wisdom, and mature judgment. The Committee and its subcommittees should contain diverse experience in business, government, education, and science and technology, and in areas that are relevant to EMSL's mission and national and international activities.

Members must be willing to devote sufficient time to carry out their duties and responsibilities effectively, and should be committed to serve on the Committee and its subcommittees for the entire term. Members should offer their resignation in the event of any significant change in their personal circumstances, including a change in their principal job responsibilities. Members may be removed from the Committee for cause by the EMSL Director with concurrence from the PNNL Director.

\subsubsection{Terms of Service}

Committee members will serve a four-year term. Terms will be sufficiently staggered to permit continuity of operation and institutional knowledge. The EMSL Director will appoint a Chair and Vice-Chair from the Committee's external membership, with the Vice-Chair succeeding the Chair at the end of each Chair's term. A member serving as Chair may be granted a one-year extension of membership, in no case to exceed a total of five years of service on the Committee.

Point of Contact: EMSL Director, Allison Campbell

Note: Level 1 Document; Requires DOE approval
7.1

Previous Revision: none
Current Revision: December 30, 2005; Operations Manual Rev.3, June, 2006 Last Reviewed: Last Reviewed: February 17, 2009 


\subsubsection{EMSL Staff Coordinator}

The EMSL Director will appoint a staff member to provide staff support to the committee, which includes organizing the meetings, taking meeting minutes for the committee, maintaining a list of candidates to fill committee vacancies, and other duties as assigned by the EMSL Director.

\subsection{Governance Principles}

EMSL's business is conducted by Battelle employees, managers and executives, under the direction of the EMSL Director to enhance the long-term value of EMSL for the Department of Energy, Pacific Northwest National Laboratory, and the public.

\subsubsection{Role of Management}

The operations and management of EMSL are vested in the EMSL Director and his/her management team. The management team is responsible for assuring that the objectives of EMSL are accomplished within the policies, DOE prime contract and legal environment within which PNNL operates. The management team is responsible for assuring that the assets of PNNL and DOE are protected.

\subsection{Committee Activities and Duties}

\subsubsection{Frequency of Meetings}

The Committee will meet annually at EMSL. In addition, each member is encouraged to have at least one additional annual visit to EMSL in order to gain in-depth knowledge of relevant activities.

\subsubsection{Quorum}

The Committee may conduct business where a quorum of its members is present; such quorum shall consist of at least fifty (50) percent of the members, and shall include the Committee Chair or Vice-Chair. During each scheduled meeting, the Committee shall review and discuss reports by management on the performance of EMSL, its plans and prospects, as well as immediate issues facing EMSL. Committee members are expected to prepare for and attend all scheduled meetings of the Committee and any subcommittees on which they serve. Delegates are not permitted.

\subsubsection{Setting Committee Agenda}

Prior to each Committee meeting, the EMSL Director will discuss the planned agenda items for the meeting with the Committee's Chair. The EMSL Director and the EMSL Staff Coordinator shall determine the nature and extent of information that shall be provided to the members in advance of each scheduled Committee meeting. Members are urged to make suggestions for agenda items, or additional pre-meeting materials, to the EMSL Director, the Committee Chair, or the EMSL Staff Coordinator at any time. 


\subsubsection{Formation of Subcommittees}

The Committee may create new subcommittees or terminate existing subcommittees as it deems necessary and appropriate. The chair of each subcommittee shall be a member of the SAC, and shall be nominated and approved by the Committee. Subcommittee members are appointed by the subcommittee chair, and may include members of the SAC, UAC, EMSL management or staff, or other PNNL or non-PNNL qualified persons. Subcommittee duties are nondelegable. Subcommittee members may participate by telephone or videoconference.

Each subcommittee may conduct business where a quorum of its members is present; such quorum shall consist of at least fifty (50) percent of the members, and shall include the subcommittee chair. Committee members who are not members of a particular subcommittee are welcome to attend meetings of any subcommittee in a non-voting status. Subcommittee minutes will be prepared as directed by each subcommittee chair.

The subcommittee chairs report the minutes of their meetings, including recommendations for Committee approval, to the full SAC following each meeting of the respective subcommittees. The subcommittees may hold meetings in conjunction with the full Committee.

\subsubsection{Self-Assessment}

The Committee should perform an annual self-assessment in the form of a survey questionnaire. The survey questions will be formulated by the Committee Chair and Vice-Chair with the assistance of the EMSL Staff Coordinator, and will ask for evaluations of the effectiveness of the Committee and subcommittees, and the responsiveness of EMSL to SAC recommendations. The survey will be sent sufficiently in advance of the annual meeting to allow time for the responses to be summarized by the Vice-Chair for presentation to the Committee at the meeting. The assistance of an independent expert/consultant may be utilized every other year.

\subsubsection{Reimbursement or Honoraria for Committee Members}

The EMSL Director has the responsibility for setting the reimbursement or honoraria available to non-Battelle members of the Committee. In discharging this duty, the EMSL Director will be guided by two goals: reimbursement or honoraria should be fairly applied to members for work or costs incurred to support the Laboratory, and the structure should be simple, transparent, and easy for stakeholders to understand.

\subsubsection{Access to EMSL Management}

Committee members are encouraged to contact senior managers of EMSL as necessary to fulfill their duties. Meetings should be coordinated through the EMSL Director's office or the Committee’s EMSL Staff Coordinator.

\subsubsection{Committee Member Orientation}

The EMSL Director and the EMSL Staff Coordinator are responsible for providing an orientation for Committee members, and for periodically providing materials or briefing sessions for members on subjects that would assist them in discharging their duties. Each new member to the Committee will be invited to spend a day at EMSL for personal briefing by senior management on EMSL’s strategic plans and its key policies and practices. 



\subsection{User Advisory Committee Charter}

\subsection{Committee Function and Objectives}

The User Advisory Committee (UAC or Committee) is an independent body charged with providing objective, timely advice, and recommendations to the leadership of the William R. Wiley Environmental Molecular Sciences Laboratory (EMSL) with respect to the user experience. The Committee reports directly to the EMSL Director and will serve as the official voice of the user community in its interactions with EMSL management. This charter defines the membership, responsibilities, and structure of the UAC.

\subsection{Membership}

\subsubsection{Size of Committee and Selection Process}

The UAC shall have 14 members consisting of the Chair, Vice-Chair and 12 members; no more than two members shall be from the same institution. The 14 members shall be elected by the EMSL user community using electronic ballot or other method as deemed appropriate by the UAC. Terms for members shall begin on January 1 following an election in the fall. In order to ensure representation from all the EMSL scientific facilities, there shall be one member representing each facility. The remaining positions shall be considered "member-at-large" positions. Election of members shall be by simple pluralities of votes cast. The Chair will fill vacant UAC positions by initiating a call for nominations using a means he/she deems appropriate. Maintaining representation for each of the EMSL facilities will be the responsibility of the Chair. When a member representing a facility is replaced, the Chair will select nominees that are qualified for the position before a full vote.

The Chair and Vice-Chair may not be PNNL staff members. The UAC Chair has an ex officio seat on the EMSL Science Advisory Committee.

\subsubsection{Qualifications}

Members of the Committee and its subcommittees should possess the highest personal and professional ethics, integrity and values, and be committed to representing the long-term interests of EMSL and the EMSL mission. They must also have an inquisitive and objective perspective, practical wisdom and mature judgment. The Committee and its subcommittees should contain diverse experience in business, government, education, science and technology, and areas that are relevant to EMSL's mission and national and international activities.

All members are expected to be active users of the facility within the last two years and are expected to be active as a user at some point during their tenure on the committee.

Members must be willing to devote sufficient time to carrying out their duties and responsibilities effectively, and should be committed to serve on the Committee and its subcommittees for the entire term. Members should offer their resignation in the event of any significant change in their personal circumstances, including a change in their principal job responsibilities.

Members may be removed from the Committee for cause by the EMSL Director.

Point of Contact : EMSL Director, Allison Campbell

Note: Level 1 Document; Requires DOE approval
8.1

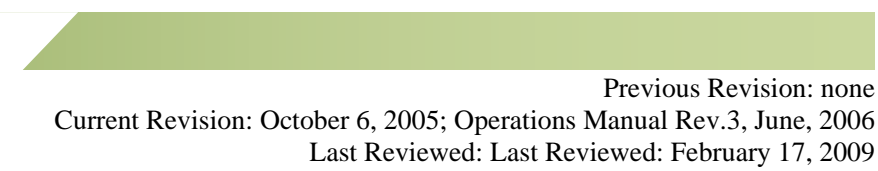




\subsubsection{Terms of Service}

Committee members will serve four-year terms. Elections will be held every other year to elect seven new members. Staggering of the terms will permit continuity of operation and institutional knowledge. The UAC shall have a Chair and a Vice-Chair, each serving two-year terms. Subsequent to the election of new UAC members, the UAC shall select a Vice-Chair from among the members of the Committee. The Vice-Chair shall serve during the ensuing two-year period and succeed to Chair after the following election. If the office of Chair becomes vacant, the Vice-Chair shall assume the position of Chair and an interim Vice-Chair shall be chosen to serve until the following election only.

Neither the Chair nor Vice-Chair shall be an employee of PNNL or Battelle.

\subsubsection{EMSL Staff Coordinator}

The EMSL Director will appoint a staff member to provide staff support to the UAC, which includes organizing the meetings, taking meeting minutes for the committee, maintaining a list of candidates to fill committee vacancies, and other duties as assigned by the UAC Chair.

\subsection{Governance Principles}

EMSL's business is conducted by Battelle employees, managers and executives, under the direction of the EMSL Director, to enhance the long-term value of EMSL for the Department of Energy, Pacific Northwest National Laboratory, and the public.

\subsubsection{Role of Management}

The operations and management of EMSL are vested in the EMSL Director and his/her management team. The management team is responsible for assuring that the objectives of EMSL are accomplished within the policies, DOE prime contract, and legal environment within which PNNL operates. The management team is responsible for assuring that the assets of PNNL and DOE are protected.

\subsubsection{Role of the User Advisory Committee}

The UAC provides input to the EMSL Director regarding user concerns, provides a forum for keeping the community informed about issues impacting users at EMSL, and serves as an advocacy group for environmental molecular science. The responsibilities of the UAC include, but are not limited to, the following:

a. Provide a clear channel for the exchange of information and advice between the investigators who perform research at EMSL and the facility's management.

b. Provide a formal vehicle for EMSL users to transmit concerns and recommendations to the EMSL Director regarding matters affecting the user community.

c. Design and oversee the Users Meeting.

d. Provide advice and recommendations to the EMSL Director on how to facilitate the effective use of EMSL. This may also include user interests in access, proposal review, equipment status, and equipment renewal, time allotment, strategic investments, as well as recommendations for integration of the various demands on EMSL equipment and staff resources to optimize utilization and impact.

Point of Contact : EMSL Director, Allison Campbell

Note: Level 1 Document; Requires DOE approval
8.2

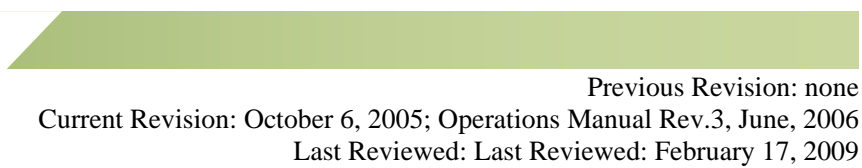


e. Nominate active users for future membership on the Committee.

f. Provide advice on other matters affecting EMSL at the request of the EMSL Director.

\subsection{Committee Activities and Duties}

\subsubsection{Frequency of Meetings}

The Committee will meet one time each year at EMSL. If deemed necessary by the UAC Chair, additional meetings may be called.

\subsubsection{Quorum}

The Committee may conduct business where a quorum of its members is present; such quorum shall consist of at least fifty (50) percent of the members, and shall include the Committee Chair or Vice Chair. Committee members are expected to prepare for and attend all scheduled meetings of the Committee and any subcommittees on which they serve.

\subsubsection{Setting Committee Agenda}

Prior to each Committee meeting, the EMSL Director will discuss the agenda items for the meeting with the Committee Chair. The Committee Chair and the EMSL Staff Coordinator shall determine the nature and extent of information that shall be provided to the members in advance of each scheduled committee meeting. Members are urged to make suggestions for agenda items or additional pre-meeting materials to the EMSL Director, the Committee Chair, or the EMSL Staff Coordinator at any time.

\subsubsection{Formation of Subcommittees}

The Committee may create new subcommittees or terminate existing subcommittees as it deems necessary and appropriate. The chair of each subcommittee shall be a member of the UAC, and shall be nominated and approved by the Committee. Subcommittee members are appointed by the subcommittee chair, and may include members of the SAC, UAC, EMSL management or staff, or other PNNL or non-PNNL qualified persons.

Subcommittee duties cannot be delegated. Subcommittee members may participate by telephone or videoconference.

Each subcommittee may conduct business where a quorum of its members is present; such quorum shall consist of at least fifty (50) percent of the members (including telephone or videoconference), and shall include the subcommittee chair. Committee members who are not members of a particular subcommittee are welcome to attend meetings of any subcommittee. Subcommittee minutes will be prepared as directed by each subcommittee chair.

The subcommittee chairs report the minutes of their meetings, including recommendations for Committee approval, to the full Committee following each meeting of the respective subcommittees. The subcommittees may hold meetings in conjunction with the full Committee. 


\subsubsection{Self-Assessment}

The Committee should perform an annual self-assessment in the form of a survey questionnaire. The survey questions will be formulated by the Committee Chair and Vice-Chair with the assistance of the EMSL Staff Coordinator, and will ask for evaluations of the effectiveness of the Committee and subcommittees, and the responsiveness of EMSL to UAC recommendations. The survey will be sent sufficiently in advance of the annual meeting to allow time for the responses to be summarized by the Vice-Chair for presentation to the Committee at the meeting. The assistance of an independent expert/consultant may be utilized every other year.

\subsubsection{Reimbursement or Honoraria for Committee Members}

The EMSL Director has the responsibility for setting the reimbursement or honoraria available to non-Battelle members of the Committee. In discharging this duty, the EMSL Director will be guided by two goals: reimbursement or honoraria should be fairly applied to members for work or costs incurred to support EMSL, and the structure should be simple, transparent, and easy for stakeholders to understand.

\subsubsection{Access to EMSL Management}

Committee members are encouraged to contact senior managers of EMSL as necessary to fulfill their duties. Meetings should be coordinated through the EMSL Director's office or the Committee's EMSL Staff Coordinator.

\subsubsection{Committee Member Orientation}

The EMSL Director and the EMSL Staff Coordinator are responsible for providing an orientation for Committee members, and for periodically providing materials or briefing sessions for members on subjects that would assist them in discharging their duties. Each new member to the Committee will be invited to spend a day at EMSL for personal briefing by senior management on EMSL’s strategic plans and its key policies and practices.

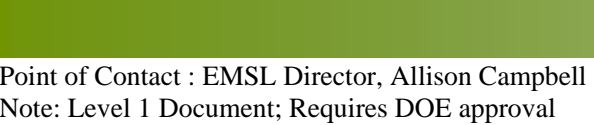

Note: Level 1 Document; Requires DOE approval
8.4

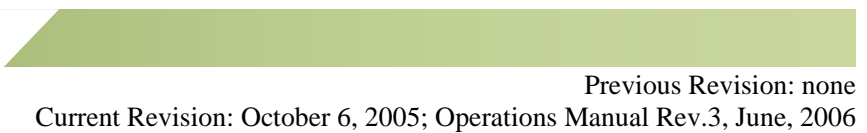
Last Reviewed: Last Reviewed: February 17, 2009 


\subsection{Charging Guidance for EMSL User Facility Staff}

This section provides EMSL organization staff and other PNNL staff supporting the EMSL User Project with information for determining when to charge non-proprietary work to the EMSL Operations project and when to charge to other projects that are using EMSL resources. This summary charging guidance may be supplemented by the individual Scientific Facility's guidance on charging. A guiding principle is that users are treated equitably with respect to charging. Charging user support activities to the EMSL Operations project (see below) will apply the same logic whether the user is from PNNL or is an external (non-PNNL) user. However, on-site users are treated differently than remote users. Onsite users may be charged for some support where remote users generally are not.

EMSL defines a User as follows:

Any individual who makes use of the facility as part of an active usage proposal in the EMSL Usage System is considered an EMSL user.

The Department of Energy's Office of Biological and Environmental Research provides programmatic funding for the operation and maintenance of EMSL as a user facility, frequently referred to as the EMSL Operations budget. Users located at the PNNL campus are always considered onsite users for charging purposes.

\subsection{Support Activities Charged to the EMSL Project}

The EMSL Operations budget is managed through a work breakdown structure (WBS), which captures costs in a consistent manner across EMSL user facility. This section provides guidance on appropriate charging within the EMSL Operations project's WBS.

- Management (Work that crosscuts individual proposals) — Facility Lead and administrator labor when providing management and oversight for the facility, and to support proposal calls and proposal reviews, user outreach.

- Core/Maintenance (Work to keep the equipment/facility in a ready-to-use status) — Equipment maintenance agreements, consumables, performing routine maintenance, instrument calibration, managing laboratory space.

- User Support (Anything that can be specifically assigned to a single or limited group of user proposals) - All administrative processing, including Facility Lead and administrator labor, processing users for entry into and use of EMSL and its resources; user training; and assisting users during experiments (e.g. in preparing samples); assembling, configuring, and disassembling equipment; evaluating and monitoring the progress of user research.

- Working with onsite users - the EMSL project should be charged when working with a user who is physically present with the scientific consultant.

- Capability Development (Work to create new capability or improve current capability)— New equipment, etc., which are approved through proposals to the Director’s Office.

Approval of an EMSL User Proposal does not, by itself, entitle users to expenditures on their behalf under the EMSL Operations budget.

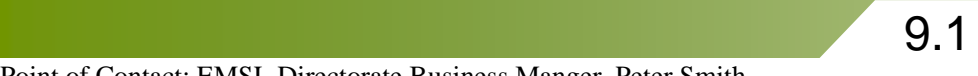

Point of Contact: EMSL Directorate Business Manger, Peter Smith

9.1
Previous Revision: October 6, 2005; Operations Manual Rev.3, June, 2006 Current Revision: February 28, 2007 Last Reviewed: March 17, 2009 


\subsection{Support Activities Charged to other projects}

EMSL staff should charge to the benefiting project or pool, other than EMSL Operations budget, when they are asked by a user to perform activities such as processing routine samples or conducting experiments that would normally be performed by and/or with the user, or to perform any other support that does not qualify for Operations project funding as outlined above.

Examples of activities that shall be charged to the user's project:

- On-site user requests for EMSL staff to run samples, perform analyses, or contribute to a report that the user is able to perform but chooses not to do.

- $\quad$ On-site user is defined as being on the PNNL campus, or in certain cases where EMSL-owned equipment is taken to a remote location for field work.

- EMSL staff travel to a conference at the user's request to present information specific to non-EMSL projects (i.e., other programmatic funded research), and the conference provides limited outreach opportunity or EMSL capability discussions (i.e. it primarily benefits the programmatic funded research).

Support for properly approved proprietary proposals require full cost recovery, and as such are charged accordingly. Additionally, EMSL houses resources that were not fully purchased with the EMSL Operations funding. In these cases, a minimum of $20 \%$ of this resource is made available to the user community or the percentage purchased by the EMSL Operations funding, whichever is larger. Research performed on the percentage of these resources not owned or made available to EMSL users, is not supported by EMSL Operations funding.

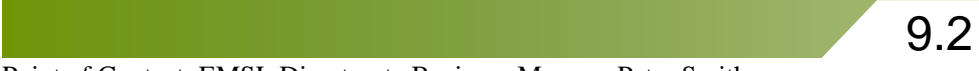

Point of Contact: EMSL Directorate Business Manger, Peter Smith

9.2
Previous Revision: October 6, 2005; Operations Manual Rev.3, June, 2006

Current Revision: February 28, 2007 Last Reviewed: March 17, 2009 


\subsection{EMSL Space Policy}

An assumption in the formulation of EMSL's space policy is that all facility space, regardless of space chargeback designation, is owned by the DOE Office of Biological and Environmental Research and managed by the EMSL Director’s Office, and that all space allocation is governed by the policies designated below.

EMSL, as a national user facility, is funded and operated to provide state-of-the-art scientific capabilities to the national and international user community in the areas of EMSL's four science themes. Due to the unique nature of this facility, priority must be given to those capabilities and individuals that significantly support the EMSL mission. Likewise, those capabilities and individuals that currently occupy the facility and are determined to not directly and significantly support EMSL's mission may be requested to relocate to other PNNL facilities. Costs associated with moving existing occupants are negotiated among EMSL management, PNNL management, and the affected capability's/individual's organization.

\subsection{Laboratory Space}

To be eligible for EMSL laboratory space, an individual and/or capability must be engaged in research that reflects the primary mission of EMSL:

EMSL, a national scientific user facility at Pacific Northwest National Laboratory, provides integrated experimental and computational resources for discovery and technological innovation in the environmental molecular sciences to support the needs of DOE and the nation.

Priority for laboratory space is based on the level of support the individual or capability brings to the EMSL mission. The following criteria are used to measure the level of support:

- Is the individual's research or capability in demand by EMSL users? (Capabilities that are in minimal demand by external users will not rank as highly in priority as those in more demand.)

- Has the individual's research or capability resulted, or does it have the potential to result, in high-impact publications, awards, and other external recognition?

- Is the individual's research or capability aligned with EMSL science themes?

- Is a capability being developed that has direct benefit to the user community?

Any equipment proposed to be brought into EMSL must comply with EMSL’s equipment use policy.

The following criteria are used to prioritize capabilities when new requests for laboratory space are submitted:

- Priority 1: Capabilities that are owned by EMSL and directly support EMSL's user program and science themes.

- Priority 2: Capabilities that are in high demand for supporting EMSL's user program and science themes, but that are not owned by EMSL.

Any capabilities (and staff) in EMSL who do not meet one of these two criteria will be requested to move from the building, when space needs dictate.

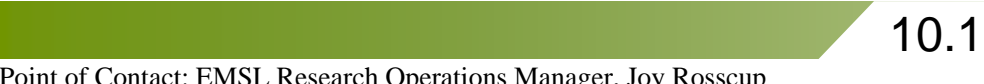

Point of Contact: EMSL Research Operations Manager, Joy Rosscup

10.1

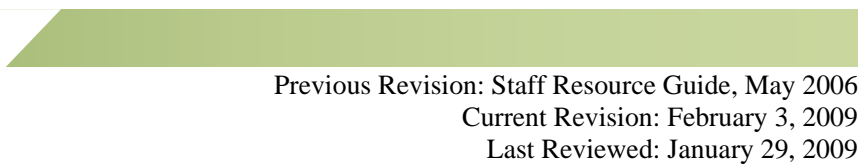




\subsubsection{Requesting EMSL Laboratory Space}

Laboratory space requests are submitted to the EMSL Research Operations Office, who works with the space point of contact for the requesting research group to identify acceptable space. The requesting group must demonstrate how the individual's research or capability supports EMSL's mission and science themes and that it effectively and efficiently uses any existing EMSL space in relation to the activities and equipment in that space. The EMSL Director or Associate Director approves all space allocations.

\subsubsection{Office Space}

To be eligible for EMSL office space, an individual must be engaged in EMSL's mission. Priority for office space will be given as follows:

- Priority 1: Staff members in the EMSL organization and their post-doctoral researchers and students.

- Priority 2: Non-PNNL staff members (external users) who have an approved user proposal for using EMSL research capabilities onsite.

- Priority 3: Non-EMSL staff and their students who occupy primary lab space or are directly supporting a lab space in EMSL.

- Priority 4: Matrixed staff who support the infrastructure of EMSL in support of its mission, including staff from PNNL's Operational Systems Directorate; Environment, Health, Safety and Security; Communications; and Business Support Services organizations.

PNNL staff who do not meet any of these criteria will be requested to move from the building, when space needs dictate.

\subsubsection{Requesting EMSL Office Space}

1. Office space requests are submitted to the EMSL Research Operations Office, who works with the space point of contact for the requesting research group to identify acceptable space.

2. The first solution is to place the occupant in space already under "control" of the requesting group. Control means the group already pays the space charge for that space.

3. The requesting group must demonstrate that they effectively and efficiently use any existing EMSL space in relation to the activities and equipment in that space.

4. If the requested space is already filled and other appropriate space cannot be identified, the requesting group can:

a. identify space outside of EMSL for the new occupant, or move existing staff out of the building so that the new occupant can assume the space,

b. request space from another EMSL group through the Operations Manager.

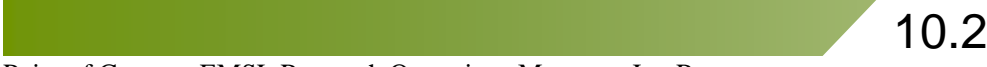

Point of Contact: EMSL Research Operations Manager, Joy Rosscup
Previous Revision: Staff Resource Guide, May 2006

Current Revision: February 3, 2009

Last Reviewed: January 29, 2009 


\subsection{Guidance and Examples Regarding Designation of User(s) in ERS bookings}

\section{User Definition}

The Environmental Molecular Sciences Laboratory (EMSL) defines a User as follows:

\section{Any individual who makes use of the facility as part of an active user proposal in the EMSL Usage System is considered an EMSL user.}

For each fiscal year, each user will be categorized as a/an:

a. Onsite User - individuals who are physically present at EMSL, at least once during the reporting period, to conduct their research.

b. Remote User, Operating Instrumentation - individuals who remotely access EMSL by logging onto EMSL's network to operate a piece of research instrumentation.

c. Remote User, Not Actively Operating Instrumentation - individuals who remotely access EMSL but do not actively operate instrumentation, (such as those who send/receive samples to/from EMSL).

\section{User Counts:}

Users are counted once per fiscal year.

EMSL developed the EMSL Resource System (ERS) to schedule and record the usage (bookings) of EMSL instruments and facilities. For the purpose of compiling user statistics on new, external, etc, users for performance metrics, bookings designate individuals meeting certain criteria as "users." This document provides guidance in determining which of the proposal participants are to be entered as "user(s)" in the ERS booking.

\section{Definitions:}

- EMSL Project - EMSL operations project funded

- External person - a non-PNNL participant on an approved usage proposal

- Non-EMSL Project - research funded by any project other than EMSL

- Onsite - on the PNNL campus but may include a location where an EMSL resource is being used in the field.

- Participant - any person listed on a usage proposal

- PNNL Staff - any PNNL staff member (may or may not be a participant on an EMSL usage proposal)

- User - the person designated in the ERS as the one interacting with EMSL instrument(s), for the purposes of recordkeeping regarding EMSL facilities.

\section{General Guidance:}

If the EMSL Project is paying for PNNL staff to work with a proposal participant, then the participant is designated as "user" on the ERS booking. If any other project is paying for the PNNL staff time, then the PNNL Staff should be designated as the user on the ERS booking.

\section{1}

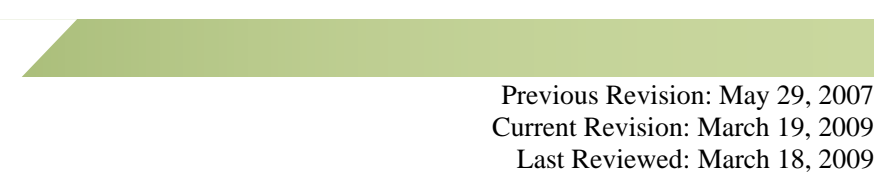




\section{Examples:}

1. If the EMSL project pays PNNL staff member(s) to work with participant(s), then the participant(s) is (are) user(s). (Usage type according the definitions above, based on the participants' activity, with the exception that any PNNL staff member cannot be remote, only on-site)

2. If a non-EMSL project pays a PNNL staff member to work on an active user proposal, then:

a. If both PNNL staff and external person(s) are onsite, then the PNNL staff and those participant(s) are users, and the usage type is Onsite.

b. If the external person(s) access EMSL remotely, then only they are user(s) and the usage type is Remote Usage... per the definitions. 


\subsection{Usage Type Definitions}

The EMSL Resource System (ERS) is used to record usage of instruments. Instrument custodians are required to input usage data into the ERS on a weekly basis and by the end of each month. The data in ERS are used to provide statistics on users, and by EMSL management to make budget decisions regarding enhancements, acquisitions, consolidation of capabilities, and strategic direction for capability growth. Time on each instrument in ERS is recorded in one of the following designations:

- Available - any time not allocated under any other Usage Type.

- On-Site Usage- Use by any individual who is part of an active user proposal in the EMSL Usage System (EUS) and who is physically present in EMSL conducting their research at any time during this ERS reservation. EXCEPTION: PNNL STAFF MEMBERS SELECTED AS USER WILL ALWAYS BE COUNTED AS ONSITE.

- Remote Usage, Operating Equipment - Use by any individual who is part of an active user proposal in the EMSL Usage System (EUS) and who is remotely accessing EMSL by logging on to the EMSL network to operate a piece of research instrumentation or to use the high performance computing system or other computer cluster from a remote location. Examples include use of the Supercomputer or remote operation of the NMR.

- Remote Usage, Other - Use by any individual who is part of an active user proposal in the EMSL Usage System (EUS) and who is accessing EMSL but does not actively operate instrumentation (e.g., sending or receiving samples/data/calculations to/from EMSL as part of a user project). Only the user that sends or receives the sample/data/calculation is entered into the EMSL Resource System (ERS) reservation. Examples include samples sent to the proteomics facility, films grown by MBE, or structures sent to modelers for calculations.

- Broken, Out of Service - Equipment is not available because it is broken or damaged to the point that it cannot be used until fixed. Enter comments to clarify this designation.

- Periodic Maintenance - Equipment is not available because periodic maintenance is being performed to keep the equipment in a ready-to-use mode and at peak performance. Enter comments to clarify this designation.

- Capability Development - Time allocated to develop a new capability and bring it on line. Capability development activities may require extended booking of the instrument. Enter comments to clarify this designation.

- Upgrade - Equipment is not available because an upgrade is being installed. Enter comments to clarify this designation.

- Continued on next page

\footnotetext{
* Reports generated from these data are used to help EMSL management and DOE understand the needs of our user community. Inadequate comments may result in the need to seek additional information when these reports are analyzed 
- EMSL Staff 5\% - Use by any individual as part of an active EMSL 5\% proposal in the EMSL Usage System (EUS). Participants recording use on an EMSL 5\% proposal will not be counted as a user.

- Unavailable, Staffing - Equipment is not available because staff are not available to operate the equipment. Operator vacations and holidays should be included in this usage category. This includes all cases where staff are unavailable due to, for example, absence from the laboratory or other commitments that make it impossible for the staff to support user activities. Additionally; "Unavailable, Staffing” can be used if EMSL user program funds are not adequate to support all of the user demands. For example; a resource has time otherwise available to support user research but cannot be used due to funding constraints, and there is work scheduled/requested to be performed. Enter comments to clarify this designation.

- Unavailable, Other - Equipment is not available for reasons other than staff unavailability. Examples include problems with the facility, and facility power outages. This may include a time when, for instance, a sample must be contained under vacuum but no experiment is on-going, thus no one else can use the resource. Enter comments to clarify this designation. ${ }^{*}$

\footnotetext{
* Reports generated from these data are used to help EMSL management and DOE understand the needs of our user community. Inadequate comments may result in the need to seek additional information when these reports are analyzed 


\title{
13.0 Non-Proprietary Use Agreement (NPUA) \& Appendices
}

\subsection{NPUA}

\author{
NONPROPRIETARY USE AGREEMENT
}

[for the]

\section{ENVIRONMENTAL MOLECULAR SCIENCES LABORATORY}

The parties to this Agreement are Battelle Memorial Institute, Pacific Northwest Division (hereinafter referred to as "Battelle”), managing the Environmental Molecular Sciences Laboratory (EMSL) under Contract No.

DE-AC05-76RL0-1830 for the United States Department of Energy (DOE) as an agent of the United States of America (hereinafter referred to as "Government"), and

(hereinafter referred to as the "User Entity"):

\section{ARTICLE I - SCOPE OF SERVICES}

a. Subject to the terms and conditions set forth below, Battelle shall make available to designated employees or representatives (hereinafter referred to as "Users," individually or collectively, as the context suggests) of User Entity, certain facilities, equipment, services, information and/or material located within the EMSL User Facility. Use of the EMSL User Facility (hereinafter referred to as the "Activity") shall be in accordance with the User's EMSL use proposal(s), which must be submitted and approved in advance.

b. Upon request by the User and at Battelle's discretion, limited support services will be provided to the User. Nonproprietary users may use the EMSL User Facility free of charge except in cases where significant modifications, extraordinary support services, and/or additional equipment or consumables are needed to meet the User's requirements. In these cases, financial support may be requested from the User. The attached Appendix A will be used in these circumstances to describe the proposal work scope and will list the related reimbursable costs. Unless completed, Appendix A will not apply.

\section{ARTICLE II - ADMISSION; PERSONNEL RELATIONSHIPS}

a. Each admission or readmission of a User to the EMSL User Facility under this Agreement shall be subject to and implemented under the applicable admission regulations and procedures of Battelle and DOE. Each User shall execute Appendix "B," which is attached hereto and made a part of this Agreement, and deliver it to Battelle on or before admission to the EMSL facility.

b. Users shall be considered employees or representatives of User Entity during all activities under this Agreement and shall not be considered employees of Battelle or DOE for any purpose. However, the occupational activities of Users shall be subject to the administrative and technical oversight of Battelle during and in connection with such participation in the Activity, and the User shall therefore abide by and comply with all applicable rules, regulations and requirements of Battelle and DOE with regard to such Activity including, but not limited to, those pertaining to security, safety, operating and health-physics procedures, access to information, hours of work, and conduct. User Entity shall obtain such agreements from each User as necessary to implement the provisions of this Agreement.

\section{ARTICLE III - SCHEDULING}

The User Entity understands and agrees (a) that the Activity is subject to the priority of Battelle's work for the Government and on a non-priority basis in regard to other users, and (b) that Battelle, through its cognizant user facility administrator, shall have sole responsibility and discretion for allocating and scheduling usage of the facilities, equipment, services, materials and/or information needed for or involved in the Activity. 


\section{ARTICLE IV - MATERIALS}

It is recognized that any material to be supplied by the User may be damaged, consumed, or lost. Materials (including residues and/or other contaminated material) remaining after performance of the work or analysis will be removed in their then condition by the User at the User's expense.

\section{ARTICLE V - INTELLECTUAL PROPERTY PROVISIONS}

Except as otherwise required by 35 U.S. Code Section 212, rights of the parties in patents, technical data, copyrights and other intellectual property shall be as set forth in Appendix C, which is attached hereto and made a part of this Agreement.

\section{ARTICLE VI - LIABILITY}

a. Neither the Government, DOE, Battelle, nor persons acting on their behalf will be responsible for any injury to or death of persons or other living things or damage to or destruction of property or for any other loss, damage or injury of any kind whatsoever resulting from the furnishing of facilities, equipment, material, information or personnel under this Agreement, and not directly resulting from the sole fault or negligence of the Government, DOE, Battelle, or persons acting on their behalf.

b. Neither the Government, DOE, Battelle, nor persons acting on their behalf will be responsible, irrespective of cause, for failure to furnish the facilities, equipment, material, information or personnel under this Agreement at any particular time or in any particular manner.

c. If and to the extent permitted by law applicable to the User Entity, the User Entity agrees to indemnify and save harmless the Government, DOE, Battelle, and persons acting on their behalf from any costs and expenses resulting from loss, damage, destruction, misuse or alteration to or of property of the U.S. Government to the extent that such loss, damage, destruction or alteration is caused or contributed to by the intentional or negligent act of User Entity or its employees or representatives.

d. The foregoing provisions of this Article VI shall have no application to public liability for nuclear incident as defined and provided for in the Atomic Energy Act of 1954, as amended, compensation for which shall be in accordance with such law.

\section{ARTICLE VII - EXPORT CONTROLS}

User Entity hereby acknowledges notice that the export of goods and/or Technical Data from the United States may require some form of export control license from the U. S. Government and that failure to obtain such export control license may result in criminal liability under the laws of the United States.

\section{ARTICLE VIII - TITLE AND ADMINISTRATION}

It is understood and agreed that this Agreement is entered into by Battelle for and on behalf of the Government; that Battelle is authorized to and will administer this Contract in other respects for DOE, unless otherwise specifically provided for herein; that administration of this Agreement may be transferred from Battelle to DOE or its designee, and in case of such transfer and notice thereof to the User Entity, Battelle shall have no further responsibilities hereunder.

\section{ARTICLE IX - TERMINATION}

Either party hereto may terminate this Agreement for any reason at any time by giving not less than thirty (30) days prior written notice to the other party. Battelle reserves the right to immediately cancel this Agreement without regard to the aforesaid written notice when cancellation of this Agreement is determined to be necessary to the national defense and security of the United States. Such termination shall only affect the term of this Agreement, and shall otherwise be without prejudice to the rights of the parties hereunder which may have previously accrued.

\section{ARTICLE X - RESERVED}




\section{ARTICLE XI — PUBLIC DISCLOSURE REQUIREMENTS}

In regards to publications or presentations resulting from work performed using the EMSL, users are required to:

a. Include an acknowledgment of the EMSL (example: "(A portion of) The research described in this paper (poster or presentation) was performed in the Environmental Molecular Sciences Laboratory, a national scientific user facility sponsored by the Department of Energy's Office of Biological and Environmental Research and located at Pacific Northwest National Laboratory.") EMSL staff can be listed on publications as appropriate, but an EMSL acknowledgment should be included as part of every publication or presentation for which EMSL capabilities made a contribution.

b. Provide to the EMSL User Services Office (PO Box 999, K8-84, Richland, WA 99352) copies or reprints of the publications.

c. Submit to the EMSL User Services Office summaries of research results for publication in the annual EMSL Activity Report.

\section{ARTICLE XII — ENTIRE AGREEMENT}

It is expressly agreed by the parties hereto that this Agreement constitutes the entire and only contract between the parties with respect to the subject matter herein; and that this Agreement cannot be amended nor any provision thereof waived except by an instrument in writing and duly executed on behalf of each of the parties hereto by the duly authorized representative of each party.

\section{SIGNATURES}

\section{BATTELLE MEMORIAL INSTITUTE}

\section{PACIFIC NORTHWEST DIVISION}

BY:

NAME (typed): Gene G. Stott

TITLE: Sr. Contract Specialist

DATE:
BY:

NAME (typed):

TITLE:

DATE: 


\subsection{Appendix A}

\section{Appendix A \\ Environmental Molecular Science Lab (EMSL) \\ Statement of Work}

[NON-PROPRIETARY]

Pursuant to the above identified Use Agreement and subject to the terms and conditions stated therein, Battelle shall provide, furnish, or otherwise make available to duly authorized employees or representatives of the User Entity the following facilities, equipment, services, material and/or information for the following purpose:

Either insert work scope or reference it as an Attachment.

Term: .Insert \# of years

Estimated Time of Use: ...As an example, this would be stated in terms of hours per day, or other more specific language.

\section{Proposed on behalf of Use Entity}

BY:

NAME (typed):

TITLE:

DATE:

\section{Accepted on behalf of Battelle}

BY:

NAME (typed):

TITLE:

DATE: 


\subsection{Appendix B}

\section{Appendix B \\ Environmental Molecular Science Lab (EMSL) Agreement Covering Obligations and Responsibilities of Users}

, (User), an employee or representative of the

(User Entity), pursuant to the User Agreement between User Entity and Battelle, is to be permitted access to and use of the Environmental Molecular Sciences Laboratory (EMSL), a user facility of the UNITED STATES DEPARTMENT OF ENERGY (DOE) which is operated by Battelle under contract with the UNITED STATES GOVERNMENT (access and use are hereinafter referred to as the "Activity"), as authorized under the Use Agreement.

The User acknowledges that he/she understands and agrees, as a condition of his/her access to or use of the aforementioned facility and/or equipment, material, services, or information of Battelle for the purpose of the above stated Activity, that:

1. Although the User will remain and employee of representative of the User Entity at all times during his/her participation in the Activity, and shall not be considered an employee of Battelle or DOE for any purpose, his/her occupational activities shall be subject to the administrative and technical oversight of Battelle during and in connection with the Activity.

2. The User shall abide by and comply with all the applicable rules, regulations, and requirements of DOE and Battelle with regard to said Activity including, but not limited to, those pertinent to security, safety, operating and healthphysics procedures, hours of work, and conduct. The User further understands and acknowledges (a) that the Activity under this Use Agreement is subject to the priority of Battelle's work for the Government and on a non-priority basis in regard to other users, and (b) that Battelle shall have sole responsibility and discretion for allocating and scheduling usage of the facilities, equipment, services, materials and/or information involved in or needed for the Activity.

3. All right, title, and interest in and to any invention or discovery made or conceived by the User in the course of or under this Use Agreement, or any patent application or patent thereon shall remain the property of the inventor.

4. Any technical data or information in any for which is generated, developed, or acquired by the User in the course of or under this Use Agreement shall remain property of the author.

5. The User further understands and agrees that:

a. All obligations and responsibilities undertaken herein shall continue in full force and effect until properly fulfilled or otherwise discharged, notwithstanding the conclusion of the User's involvement in the Activity or the termination of participant's affiliation with the User Entity;

b. All such obligations and responsibilities shall be equally applicable to and govern any extension or renewal of User's involvement in the Activity pursuant to the Use Agreement, without the necessity of executing another copy of the agreement.

c. The User has entered into no agreements with any person or party conflicting with User's obligation, agreement, or undertaking herein; and

d. Although the User shall not be entitled to obtain access to and Restricted Data or other classified information pursuant to this Use Agreement, failure to properly safeguard such classified information that may come to Used in connection with this effort may result in civil and/or criminal liability under applicable laws of the United States.

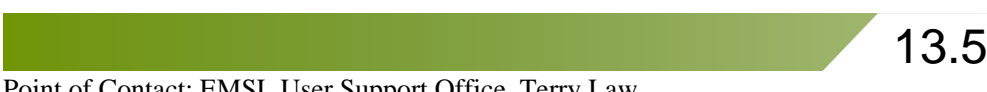

Point of Contact: EMSL User Support Office, Terry Law
Previous Revision: October 1, 1998 Current Revision: July 12, 2007 Last Reviewed: March 17, 2009 


\section{Appendix B (continued) \\ Environmental Molecular Science Lab (EMSL) Agreement Covering Obligations and Responsibilities of Users}

6. In regards to publications or presentation resulting from work performed using the EMSL, users are required to:

a. Include an acknowledgement of the EMSL (Example: "(A portion of) The research described in this paper (poster or presentation) was performed in the Environmental Molecular Sciences Laboratory, a national scientific user facility sponsored by the Department of Energy's Office of Biological and Environmental Research and located at Pacific Northwest National Laboratory.”) EMSL staff can be listed on publications as appropriate, but an EMSL acknowledgement should be included as part of every publication or presentation for which EMSL capabilities made a contribution.

b. PNNL/EMSL research staff are often listed as co-authors on publications resulting from User research performed in EMSL due to their significant scientific contribution. If PNNL/EMSL staff are listed as co-authors, you are required to notify the staff member prior to submission so that the publication can be reviewed and process through PNNL's clearance system.

c. Provide to the EMSL User Services Office (POB 999, K8-84, Richland, WA 99352) copies or reprints of the publications.

d. Submit to the EMSL User Services Office summaries of research results for publication in the annual EMSL Activity Report.

User Signature:

Name (print or type):

User Title:

Business Address:

Date: 


\subsection{Appendix C}

\section{APPENDIX C NON-PROPRIETARY}

\section{PATENT RIGHTS - USER FACILITIES (CLASS WAIVER)}

\section{A. DEFINITIONS}

1. "User” means the entity with which this Agreement is made.

2. "Subject Invention" means any invention or discovery of the User, conceived or first actually reduced to practice by User's employee (s) in the course of or under this Agreement, and includes any art, method, process, machine, manufacture, design, or composition of matter, or any new and useful improvement thereof, or any variety of plants, whether patented or unpatented under the patent laws of the United States of America or any foreign country.

3. "Facility Operator" means the operating contractor which manages and operates the Government-owned, contractor-operated facility where the work under this Agreement is to be performed.

4. "DOE” means the United States Department of Energy.

\section{B. RIGHTS OF THE USER}

1. Election to retain rights - Subject to the provisions of paragraph C. (2) of this clause, the User may retain the entire right, title and interest in any patent application filed in any country on a Subject Invention reported and elected in accordance with paragraph D. of this clause and in any resulting patent secured by the User. Where appropriate, the filing of patent applications by the User is subject to DOE security regulations and requirements.

2. Minimum license - The User reserves an irrevocable, nonexclusive, paid-up license in each patent application filed in any country on a Subject Invention and any resulting patent in which the User does not elect to retain title or in which the Government acquires title. The license shall extend to the User's domestic subsidiaries and affiliates, if any, within the corporate structure of which the User is a part and shall include the right to grant sublicenses of the same scope to the extent the User was legally obliged to do so at the time this Agreement was entered into. The license shall be transferable only with approval of DOE except when transferred to the successor of that part of the User's business to which the invention pertains.

\section{RIGHTS TO GOVERNMENT}

1. Assignment to the Government - The User agrees to assign to the Government, upon request, the entire right, title, and interest in any country to each Subject Invention of the User and to each Subject Invention of Battelle to which the User has acquired title, except to the extent that rights are retained by the User under paragraph B. (1) of this clause, where the User:

a. Does not elect, pursuant to this clause to retain such rights;

b. Fails to have a patent application filed in that country on the Subject Invention or decides not to continue prosecution or not to pay any maintenance fees concerning the Subject Invention; or

c. At any time, the User no longer desires to retain title. 
2. Terms and Conditions of Waived Rights

a. To preserve the Government's residual rights to Subject Inventions, the User shall take all actions in reporting, electing, filing on, prosecuting and maintaining such rights promptly, but in any event, in sufficient time to satisfy domestic and foreign statutory and regulatory time requirements; or, if the User decides not to take appropriate steps to protect the invention rights, it shall notify DOE in sufficient time to permit the Government to file, prosecute and maintain patent applications, and any resulting patents prior to the end of such domestic or foreign statutory or regulatory time requirements.

b. The User shall convey or assure that conveyance of any executed instruments necessary to vest in the Government the rights set forth in this clause.

c. The User hereby grants to the Government a nonexclusive, nontransferable, irrevocable, paid-up license to practice or have practiced each Subject Invention throughout the world for or on behalf of the United States.

d. The User shall provide the Government a copy of any application filed on a Subject Invention promptly after such application is filed, including its serial number and filing date.

e. The User agrees that with respect to any Subject Invention in which it has acquired title, DOE has the right to require the User, or an assignee or exclusive licensee of a Subject Invention, to grant a nonexclusive, partially exclusive, or exclusive license in any field of use to a responsible applicant or applicants, upon terms that are reasonable under the circumstances, and if the User assignee, or exclusive licensee refused such a request, DOE has the right to grant such a license itself if DOE determines that:

i. Such action is necessary because the User or employee has not taken, or is not expected to take within a reasonable time, effective steps to achieve practical application of the Subject Invention in such field of use;

ii. Such action is necessary to alleviate health or safety needs which are not reasonable satisfied by the User, assignee, or their licensees; or

iii. Such action is necessary to meet requirements for public use specified by federal regulations, and such requirements are not reasonably satisfied by the User, assignee, or licensees.

f. The User shall submit written reports at reasonable intervals upon request of the Government during the term of the patent on the Subject Invention regarding:

i. The commercial use that is being made or is intended to be made of the invention; and

ii. The steps taken by the User of its transferee to bring the invention to the point of practical application or to make the invention available for license.

To the extent data or information supplied under this section is considered by the User or an assignee or exclusive licensee or assignee to be privileged and confidential and is so marked, DOE agrees that, to the extent permitted by 35 U.S.C. 202(c) (5), it will not disclose such information to persons outside the Government.

\section{INVENTION IDENTIFICATION, DISCLOSURES, AND REPORTS}

The User shall furnish the Patent Counsel a written report containing full and complete technical information concerning each Subject Invention of the User within six months after conception or first actual reduction to practice, whichever occurs first, in the course of or under this Agreement, but in any event prior to any sale, public use or public disclosure of such invention known to the User. The report shall identify the Agreement and inventor and shall be sufficiently complete in technical detail and appropriately illustrated by sketch or diagram to convey to one skilled in the art to which the invention pertains a clear understanding of the nature, purpose, operation, and to the extent known, the physical, chemical, biological, or electrical characteristics of the invention. The report should also include any election of rights under this clause. When an invention is reported under this paragraph D., it shall be presumed to have been made in the manner specified in Section (a) (1) and (2) of 42 U.S.C. 5908.

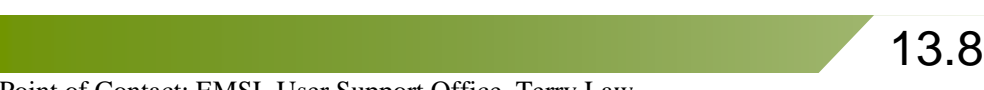

Point of Contact: EMSL User Support Office, Terry Law 


\section{E. LIMITATION OF RIGHTS}

Nothing contained in this clause shall be deemed to give the Government any rights with respect to any inventions other than a Subject Invention, except as set forth in the Facilities License of paragraph F.

\section{F. FACILITIES LICENSE}

In addition to the rights of the parties with respect to inventions or discoveries conceived or first actually reduced to practice in the course of and under this Agreement, the User agrees to and does hereby grant to the Government an irrevocable, nonexclusive paid-up license in and to any inventions or discoveries, regardless of when conceived or actually reduced to practice or acquired by the User, which at any time through completion of this Agreement are owned or controlled by the User and are incorporated into the facility as a result of this Agreement to such an extent that the facility is not restored to the condition existing prior to the Agreement (1) to practice or to have practiced by or for the Government at the facility, and (2) to transfer such license with the transfer of that facility. The acceptance or exercise by the Government of the aforesaid rights and license shall not prevent the Government at any time from contesting the enforceability, validity or scope or, or title to, any rights or patents herein licensed.

\section{G. RIGHTS TO TECHNICAL DATA}

The Government shall have the right to use, duplicate, or disclose any technical data first produced or furnished under this Agreement, and to permit others to do so.

\section{H. DELIVERABLES}

The User agrees to furnish at the request of the Facility Operator a nonproprietary technical report of the research results.

\section{LEGAL NOTICE}

The following legal notice shall be affixed to each report or publication resulting from this Agreement which may be distributed by the User:

\section{DISCLAIMER NOTICE}

This document was prepared by as a result of the use of facilities of the U.S. Department of Energy (DOE) which are managed by Battelle Memorial Institute, Pacific Northwest Division. Neither Battelle, DO E, the U.S. Government, nor any person acting on their behalf: (a) Makes any warranty or representation, express or implied, with respect to the information contained in this document; or (b) Assumes any liabilities with respect to the use of, or damages resulting from the use of any information contained in the document.

\section{PATENT AND COPYRIGHT INDEMNITY - LIMITED}

If and to the extent permitted by law applicable to the User, the User shall indemnify the Government, DOE, and Battelle and their officers, agents, and employees against liability, including costs, for infringement of any United States patent or copyright arising out of any acts required or directed by the User to be performed under the Agreement to the extent that such acts are not normally performed at the facility. Further, the foregoing indemnity shall not apply unless the User shall have been informed in a reasonable time by Battelle, DOE, or the Government of the suit or action alleging such infringement, and

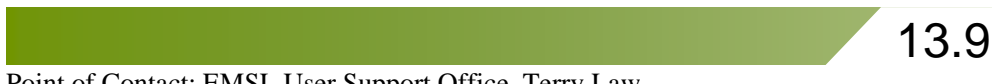


such indemnity shall not apply to a claimed infringement which is settled without the consent of the User unless required by a court of competent jurisdiction.

\section{COPYRIGHTED MATERIAL}

The User shall grant to the Government and others acting on its behalf a royalty-free, nonexclusive, irrevocable, worldwide license for Government purposes to publish, distribute, translate, duplicate, exhibit, and perform any technical data first produced in the performance of this Agreement in which the User is the author of any copyrightable expression of such technical data. 


\subsection{EMSL Staff 5\% Proposals Implementation and Utilization}

This document formalizes the procedures for review and approval of EMSL Staff 5\% proposals. The EMSL Utilization Policy states

Up to 5\% of the available time is made available for EMSL staff members to perform their independent research. Requests will be submitted through the EUS for tracking purposes. Access is subject to review and approval by the Associate Director for Scientific Resources. Access will be prioritized based on research that advances EMSL's mission.

This policy was developed to provide an opportunity for EMSL line staff to pursue their own research outside of their roles of scientific consultants for users. EMSL staff, who serve as PIs or co-PIs on non-EMSL research programs, can submit proposals to utilize EMSL resources using the EMSL 5\% proposal mechanism. These proposals are subject to internal peer and management reviews only, and participants on EMSL 5\% proposals will not be counted as Users. This mechanism does not replace user proposals by PNNL staff who pay EMSL staff to run the experiments on their behalf.

The following submission and review procedures will be followed:

- EMSL staff submit requests via the EUS, selecting the "EMSL Staff 5\%” proposal type.

- USO will assign the proposal to the Associate Director for Scientific Resources as an internal reviewer. Once the email request fires to the AD-SR, the USO will assign the appropriate capability steward.

- The Capability Steward will assign any other internal peer reviewers as deemed necessary. Note - the system is designed so PNNL staff can comment but not score proposals.

- The proposal will route through additional internal reviews as required (H\&S, radiological, environment, animal studies, human studies, etc.).

- The proposal must be fully approved before work can proceed.

- EMSL 5\% proposals can have non-EMSL staff as participants. All participants will be expected to accurately record their utilization on instruments in the ERS by selecting the appropriate proposal number and the "EMSL 5\%" usage type.

- Usage by all participants on an EMSL 5\% proposal will be reported in the Usage Breakdown (pie chart) and Utilization reports.
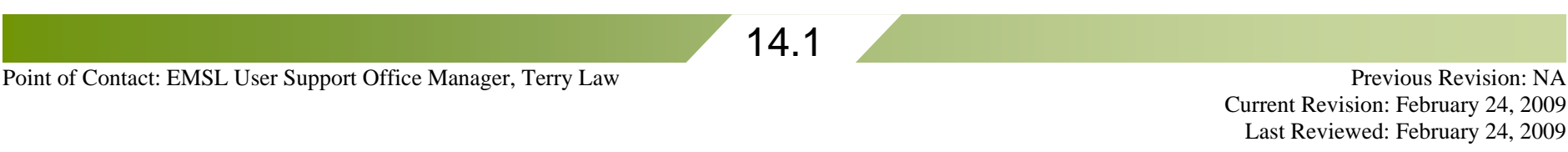



\subsection{Appeals}

Users may submit an appeal if they have concerns about how the review process was administered or about the final decision. The proposal author may submit an appeal by emailing the User Support Office with a concise (2-3 paragraphs) summary of the concerns as well as any supporting arguments for reversing the decision. All appeals are reviewed by the Appeals Committee, headed by EMSL's Chief Science Officer. The User Support Office will coordinate with the committee, and notify the user of the committee's decision within 4 weeks from receipt of the appeal. All decisions by the Appeals Committee are final. 



\subsection{EMSL Partner Proposals for Capability Development}

\subsection{Definition}

Partner proposals are submitted by individuals or groups who wish to partner with EMSL staff to enhance an existing capability or develop and build unique new capabilities that enhance EMSL's user program. Capability development efforts that support environmental molecular sciences and which utilize collaborative multidisciplinary teams, pooled or leveraged resources, unique operating environments, or other resources which may be beyond those available to individual researchers or teams are encouraged. Partner proposals are intended to leverage expertise, capability, and resources that maximize impact for EMSL, the partner, and future users. In return for co-development, EMSL partner users may have priority access to the new capability for a negotiated and specified period (subject to EMSL Advisory Committees review and approval). Proposals may be in response to a specific call or submitted at any time. The award and timing of EMSL Partner Projects are contingent upon availability of EMSL resources.

Two-page Letters of Intent (LOI) are used to initiate a dialog with EMSL's Chief Technology Officer on suitability, interest, and need for the capability. Partner users are encouraged to work with appropriate EMSL Capability Stewards or other technical contacts in preparing their Letter of Intent, which should include initial discussion of need, approach, resources, partner contributions, impact, and proposed team.

Partner users with successful LOI's will be asked to interface and work with EMSL staff in refining and developing full proposals (6-page maximum) that meet identified EMSL capability needs and are consistent with EMSL strategy, science themes, and technology thrusts.

\subsection{Review Process - Letters of Intent}

Letters of Intent will be submitted by partner user and will be reviewed by a panel consisting of the Chief Technology Officer, the Chief Science Officer, the Associate Director for Scientific Resources, and the Lead Scientists. The User Support Office Manager will be a non-voting member and serve as Secretary for the meetings. Review criteria will include strategic alignment, user/scientific impact and need, and resource and time requirements. Interaction, deliberation, and refinement of concepts with the Committee and/or EMSL staff should be expected during the LOI review process. Upon review and approval, the Chief Technology Officer or delegate will contact the partner user and request a full proposal, along with specific needs, considerations, or contacts to be addressed.

\subsection{Review Process - Full Proposals}

Full proposals are to be submitted to the EMSL User Portal (https://eus.emsl.pnl.gov/Portal/). Proposals will be reviewed by (selected) members of EMSL's advisory committees (Scientific Advisory Committee, User Advisory Committee) and an EMSL panel consisting of the Chief Technology Officer, the Chief Science Officer, the Associate Director for Scientific Resources, selected Lead Scientists, and other ad-hoc members as may be required for technical evaluation. The Lead Scientist(s) will be responsible for gathering input from appropriate Capability Steward(s) prior to the review panel meeting. The User Support Office manager will be a non-voting member and serve as Secretary for the meetings. Review criteria will include strategic alignment, user/scientific impact and need, and resource and time requirements. All meritorious proposals will be additionally be reviewed by the EMSL Chief Operations Officer as part of the approval process. The Chief Technology Officer will be responsible for communicating final approval decisions to the proposal authors.

\footnotetext{
Point of Contact: Dave Koppenaal, EMSL Chief Technology Officer 